\title{
Laminated sediments in the Bering Sea reveal atmospheric teleconnections to Greenland climate on millennial to decadal timescales during the last deglaciation
}

\author{
H. Kuehn ${ }^{1,2}$, L. Lembke-Jene ${ }^{1}$, R. Gersonde ${ }^{1,2}$, O. Esper ${ }^{1,2}$, F. Lamy ${ }^{1,2}$, H. Arz ${ }^{3}$, G. Kuhn ${ }^{1}$, and R. Tiedemann ${ }^{1}$ \\ ${ }^{1}$ Alfred-Wegener-Institut Helmholtz-Zentrum für Polar- und Meeresforschung, Bremerhaven, Germany \\ ${ }^{2}$ MARUM Zentrum für Marine Umweltwissenschaften, Bremen, Germany \\ ${ }^{3}$ IOW - Leibniz Institut für Ostseeforschung, Warnemünde, Germany \\ Correspondence to: H. Kuehn (hartmut.kuehn@awi.de)
}

Received: 4 April 2014 - Published in Clim. Past Discuss.: 6 June 2014

Revised: 18 October 2014 - Accepted: 10 November 2014 - Published: 16 December 2014

\begin{abstract}
During the last glacial termination, the upper North Pacific Ocean underwent dramatic and rapid changes in oxygenation that lead to the transient intensification of oxygen minimum zones (OMZs), recorded by the widespread occurrence of laminated sediments on circumPacific continental margins. We present a new laminated sediment record from the mid-depth $(1100 \mathrm{~m})$ northern Bering Sea margin that provides insight into these deglacial OMZ maxima with exceptional, decadal-scale detail. Combined ultrahigh-resolution micro-X-ray-fluorescence (microXRF) data and sediment facies analysis of laminae reveal an alternation between predominantly terrigenous and diatom-dominated opal sedimentation. The diatomaceous laminae are interpreted to represent spring/summer productivity events related to the retreating sea ice margin. We identified five laminated sections in the deglacial part of our site. Lamina counts were carried out on these sections and correlated with the Bølling-Allerød and Preboreal phases in the North Greenland Ice Core (NGRIP) oxygen isotope record, indicating an annual deposition of individual lamina couplets (varves). The observed rapid decadal intensifications of anoxia, in particular within the Bølling-Allerød, are tightly coupled to short-term warm events through increases in regional export production. This dependence of laminae formation on warmer temperatures is underlined by a correlation with published Bering Sea sea surface temperature records and $\delta^{18} \mathrm{O}$ data of planktic foraminifera from the Gulf of Alaska. The rapidity of the observed changes strongly implies a close atmospheric teleconnection between North $\mathrm{Pa}$ -
\end{abstract}

cific and North Atlantic regions. We suggest that concomitant increases in export production and subsequent remineralization of organic matter in the Bering Sea, in combination with oxygen-poor waters entering the Being Sea, drove down oxygen concentrations to values below $0.1 \mathrm{~mL} \mathrm{~L}^{-1}$ and caused laminae preservation. Calculated benthic-planktic ventilation ages show no significant variations throughout the last deglaciation, indicating that changes in formation rates or differing sources of North Pacific mid-depth waters are not prime candidates for strengthening the OMZ at our site. The age models established by our correlation procedure allow for the determination of calendar age control points for the Bølling-Allerød and the Preboreal that are independent of the initial radiocarbon-based chronology. Resulting surface reservoir ages range within 730-990 yr during the BøllingAllerød, 800-1100 yr in the Younger Dryas, and 765-775 yr for the Preboreal.

\section{Introduction}

The last glacial termination is characterized by the widespread decrease of oxygen concentrations at mid-depth in the world ocean (Jaccard and Galbraith, 2012). In the North Pacific, this prominent reduction led to the expansion of oxygen minimum zones (OMZs), culminating in the formation of anoxic, laminated sediment sequences at several continental margin locations (Fig. 1). Examples include the Santa Barbara Basin (e.g., Behl and Kennett, 1996), the Gulf 
Table 1. Sediment cores from the Bering Sea containing laminated intervals during the last deglaciation. Depths are given in meter below sea level (m b.s.1.).

\begin{tabular}{|c|c|c|c|c|}
\hline Sediment core & Latitude & Longitude & Depth (m b.s.1.) & Literature \\
\hline SO202-10-5 & $52^{\circ} 44.57^{\prime} \mathrm{N}$ & $179^{\circ} 50.87^{\prime} \mathrm{E}$ & 1470 & Gersonde (2012) \\
\hline SO202-11-2 & $53^{\circ} 06.67^{\prime} \mathrm{N}$ & $178^{\circ} 53.99^{\prime} \mathrm{E}$ & 2703 & Gersonde (2012) \\
\hline SO202-12-1 & $54^{\circ} 03.04^{\prime} \mathrm{N}$ & $179^{\circ} 05.24^{\prime} \mathrm{E}$ & 2109 & Gersonde (2012) \\
\hline SO202-12-3 & $54^{\circ} 03.04^{\prime} \mathrm{N}$ & $179^{\circ} 05.24^{\prime} \mathrm{E}$ & 2109 & Gersonde (2012) \\
\hline SO202-13-5* & $54^{\circ} 58.72^{\prime} \mathrm{N}$ & $177^{\circ} 57.42^{\prime} \mathrm{E}$ & 1382 & Gersonde (2012) \\
\hline SO202-14-3 & $56^{\circ} 47.19^{\prime} \mathrm{N}$ & $178^{\circ} 49.45^{\prime} \mathrm{E}$ & 3821 & Gersonde (2012) \\
\hline SO202-15-5 & $59^{\circ} 30.76^{\prime} \mathrm{N}$ & $179^{\circ} 51.00^{\prime} \mathrm{W}$ & 3129 & Gersonde (2012) \\
\hline SO202-17-1 & $60^{\circ} 07.39^{\prime} \mathrm{N}$ & $179^{\circ} 27.95^{\prime} \mathrm{W}$ & 1066 & Gersonde (2012) \\
\hline SO202-18-3 & $60^{\circ} 07.60^{\prime} \mathrm{N}$ & $179^{\circ} 26.67^{\prime} \mathrm{W}$ & 1111 & Gersonde (2012); this study \\
\hline SO202-18-6 & $60^{\circ} 07.60^{\prime} \mathrm{N}$ & $179^{\circ} 26.61^{\prime} \mathrm{W}$ & 1107 & Gersonde (2012); this study \\
\hline SO202-19-2 & $57^{\circ} 39.05^{\prime} \mathrm{N}$ & $175^{\circ} 40.69^{\prime} \mathrm{W}$ & 1752 & Gersonde (2012) \\
\hline SO202-20-1 & $55^{\circ} 08.68^{\prime} \mathrm{N}$ & $171^{\circ} 04.95^{\prime} \mathrm{W}$ & 2984 & Gersonde (2012) \\
\hline SO202-21-1 & $54^{\circ} 47.35^{\prime} \mathrm{N}$ & $170^{\circ} 19.68^{\prime} \mathrm{W}$ & 1911 & Gersonde (2012) \\
\hline SO202-22-2 & $54^{\circ} 34.45^{\prime} \mathrm{N}$ & $168^{\circ} 48.66^{\prime} \mathrm{W}$ & 1482 & Gersonde (2012) \\
\hline SO202-22-4 & $54^{\circ} 34.41^{\prime} \mathrm{N}$ & $168^{\circ} 48.62^{\prime} \mathrm{W}$ & 1476 & Gersonde (2012) \\
\hline SO201-2-114 & $59^{\circ} 13.87^{\prime} \mathrm{N}$ & $166^{\circ} 59.32^{\prime} \mathrm{E}$ & 1376 & Max et al. (2012) \\
\hline IODP U1339 & $54^{\circ} 40.02^{\prime} \mathrm{N}$ & $169^{\circ} 58.902^{\prime} \mathrm{W}$ & 1867.5 & Takahashi et al. (2011) \\
\hline IODP U1340 & $53^{\circ} 24.001^{\prime} \mathrm{N}$ & $179^{\circ} 31.297^{\prime} \mathrm{W}$ & 1294.6 & Takahashi et al. (2011); Schlung et al. (2013) \\
\hline IODP U1341 & $54^{\circ} 02.0025^{\prime} \mathrm{N}$ & $179^{\circ} 0.49992^{\prime} \mathrm{E}$ & 2139.5 & Takahashi et al. (2011) \\
\hline IODP U1342 & $54^{\circ} 49.699^{\prime} \mathrm{N}$ & $176^{\circ} 55.003^{\prime} \mathrm{E}$ & 818.6 & Takahashi et al. (2011) \\
\hline IODP U1343 & $57^{\circ} 33.399^{\prime} \mathrm{N}$ & $175^{\circ} 48.966^{\prime} \mathrm{W}$ & 1952.9 & Takahashi et al. (2011) \\
\hline IODP U1345 & $60^{\circ} 09.1917^{\prime} \mathrm{N}$ & $179^{\circ} 28.204^{\prime} \mathrm{W}$ & 1007.8 & Takahashi et al. (2011) \\
\hline HLY02-02-3JPC & $60^{\circ} 07.674^{\prime} \mathrm{N}$ & $179^{\circ} 26.508^{\prime} \mathrm{W}$ & 1132 & Cook et al. (2005) \\
\hline HLY02-02-51JPC & $54^{\circ} 33.192^{\prime} \mathrm{N}$ & $168^{\circ} 40.014^{\prime} \mathrm{W}$ & 1467 & Cook et al. (2005); Caissie et al. (2010) \\
\hline $\mathrm{PC}-23 \mathrm{~A}$ & $60^{\circ} 09.52^{\prime} \mathrm{N}$ & $179^{\circ} 27.82^{\prime} \mathrm{W}$ & 1002 & Itaki et al. (2009); Kim et al. (2011) \\
\hline PC-24A & $60^{\circ} 15.70^{\prime} \mathrm{N}$ & $179^{\circ} 25.34^{\prime} \mathrm{W}$ & 852 & Kim et al. (2011) \\
\hline PC-25A & $60^{\circ} 04.48^{\prime} \mathrm{N}$ & $179^{\circ} 27.78^{\prime} \mathrm{W}$ & 1152 & Kim et al. (2011) \\
\hline BOW-12A & $53^{\circ} 23.47^{\prime} \mathrm{N}$ & $179^{\circ} 33.47^{\prime} \mathrm{W}$ & 1287 & Okada et al. (2005); Tanaka and Takahashi et al. (2005) \\
\hline UMK-3A & $54^{\circ} 25.22^{\prime} \mathrm{N}$ & $170^{\circ} 13.38^{\prime} \mathrm{W}$ & 1892 & Okada et al. (2005); Tanaka and Takahashi et al. (2005) \\
\hline
\end{tabular}

* Magnetic susceptibility pattern and XRF data suggest that upper $15 \mathrm{ka}$ are missing (Gersonde 2012).

of California (e.g., Kennett and Ingram, 1995; Zheng et al., 2000), the continental margins off Japan (Ikehara et al., 2006; Shibahara et al., 2007), the southeast Alaska Margin (Davies et al., 2011), and multiple sites located at intermediate depth in the Bering Sea (Fig. 1, Table 1 and cf., e.g., Cook et al., 2005; Itaki et al., 2009; Schlung et al., 2013).

The causes for the occurrence of laminations and hence significant decreases in oxygen concentration of bottom waters are discussed controversially. While some studies propose changes in the ventilation of intermediate waters and see no unambiguous evidence for higher export production (Kennett and Ingram, 1995; Zheng et al., 2000), others argue for increased export productivity that would contribute to anoxic conditions (Mix et al., 1999; Ortiz et al., 2004; Davies et al., 2011), or an interaction of both higher export production and ventilation changes (Cook et al., 2005; Shibahara et al., 2007). In records from lower North Pacific latitudes a strong coupling to North Atlantic climate was observed on millennial timescales in laminated sediments from the Santa Barbara Basin, which closely resemble Dansgaard-Oeschger- type temperature changes of the Greenland Ice Sheet Project 2 (GISP2) ice core during the past $60 \mathrm{kyr}$ (Kennett and Ingram, 1995; Hendy et al., 2002). Furthermore, a close atmospheric climate teleconnection between the North Atlantic and North Pacific has been proposed in several modeling studies (Mikolajewicz et al., 1997; Okumura et al., 2009). For the Bering Sea, it was shown that laminated sediments formed during warm phases of the Bølling-Allerød (14.64$12.85 \mathrm{ka})$ and the early Holocene (10.3-11.7 ka; e.g., Cook et al., 2005; Schlung et al., 2013). However, how closely laminated high-resolution sequences in the subarctic North Pacific are in fact linked to Greenland climate on shorter-thanmillennial-scale changes remains unknown.

In principle, laminated sediments bear the potential to provide insights into climatic evolution and hemispheric coupling mechanisms with an extremely high temporal resolution (Hughen et al., 2000; Bronk Ramsey et al., 2012; Nakagawa et al., 2012). While it has been shown for laminated sediments from the Santa Barbara Basin and Saanich Inlet on Vancouver Island (Nederbragt and Thurow, 2001, 2005) 


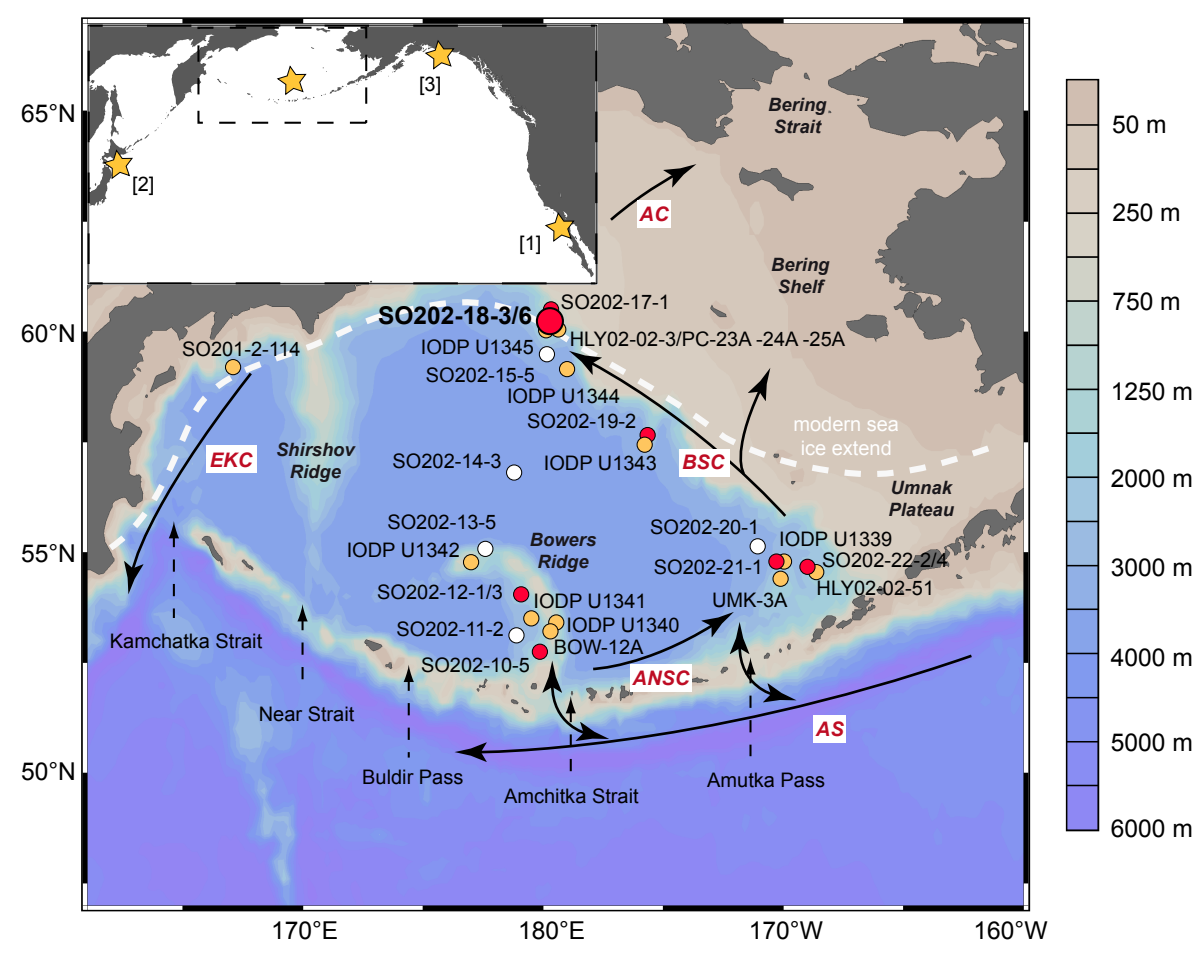

Figure 1. Bathymetric map of the Bering Sea with the position of laminated INOPEX cores (red circles) and INOPEX cores without laminations (white circles). Yellow circles mark the position of published laminated records in the Bering Sea (see Table 1 for details). The surface circulation is shown by black arrows. [AC]: Anadyr Current; [AS]: Alaska Stream; [ANSC]: Aleutian North Slope Current; [BSC]: Bering Slope Current; [EKC]: East Kamchatka Current. Dashed white line shows modern maximum sea ice extension (Reynolds et al., 2002). Dashed black arrows mark the gateways between the Bering Sea and North Pacific. Yellow stars on the small map mark location of laminated sediment records in [1] Gulf of California and Santa Barbara Basin (e.g., Behl and Kennett, 1996 ; Zheng et al., 2000), [2] near the island of Hokkaido (Ikehara et al., 2006; Shibahara et al., 2007), and [3] the southeast Alaska Margin (Davies et al., 2011). Map drawn with Ocean Data View (Schlitzer, 2002).

that each pair of laminae represents 1 year of deposition, the nature of laminations in the Bering Sea is largely unconstrained, with cases being made in previous studies for them either representing annual depositional events (Cook et al., 2005) or with no evidence found for such annual resolution (Caissie et al., 2010). Unfortunately, no laminae counts from Bering Sea sequences exist so far that shed light on this question.

In this paper, we investigate two episodically laminated sediment records from almost identical locations on the northern Bering Slope with high temporal resolution. These sites were selected from a collection of sediment cores retrieved during expedition SO202 INOPEX (Innovative NOrth Pacific EXperiment; Gersonde, 2012) to decipher deglacial changes in OMZ dynamics. With an accelerator mass spectrometry (AMS) ${ }^{14} \mathrm{C}$-anchored core chronology and detailed laminae counts, we give information on whether laminae were likely deposited annually and to what extent our records correspond to North Greenland Ice Core (NGRIP) $\delta^{18} \mathrm{O}$ time series, especially during the warm phases of the Bølling-Allerød (GI-1; Andersen et al., 2006; Rasmussen et al., 2006) and the Preboreal (11.65-10.70 ka;
Mangerud et al., 1974; van der Plicht et al., 2004). Highresolution X-ray fluorescence (micro-XRF) data and sediment $\mathrm{X}$-ray images provide information about formation processes of discrete laminae. We compare our results to existing seasonal sea surface temperature (SST) records from the Bering Sea and Greenland ice core data to deduce connections between hemispheric temperature changes and anoxia occurrence. Calculated benthic-planktic (B-P) ventilation ages will show whether water mass changes contribute to laminae formation.

\section{Study area and oceanographic setting}

The Bering Sea is the third-largest marginal sea in the world and comprises a broad continental shelf (Fig. 1). This shelf is seasonally covered with sea ice, with maximum extension occurring between March and April, including our core location, and minimum sea ice extension between July and September (Niebauer, 1980; Danielson et al., 2011). These strong seasonal contrasts are reflected in the SSTs, which range between $8{ }^{\circ} \mathrm{C}$ (summer) and $0.6^{\circ} \mathrm{C}$ (winter) at our site 


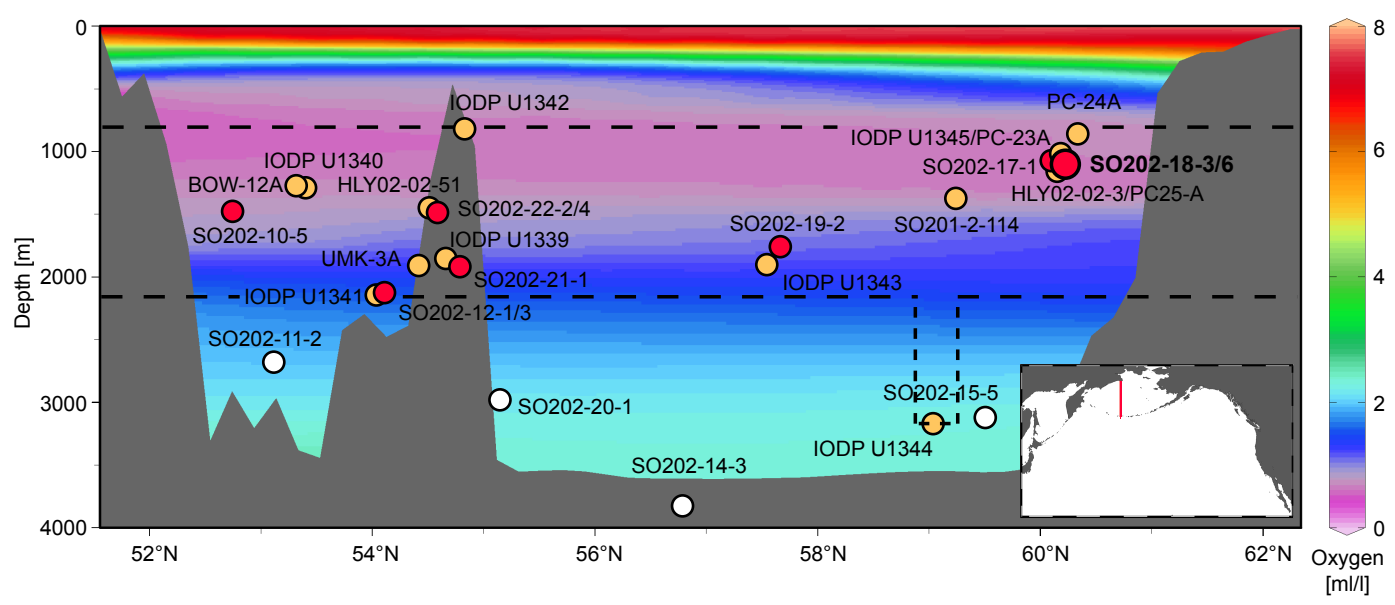

Figure 2. North-south profile through the Bering Sea and annual mean oxygen levels (Garcia et al., 2009). Red circles mark cores from this study containing laminated sediments; white circles mark cores from the INOPEX expedition without laminations. Core SO202-13-5 is not shown as the upper $15 \mathrm{kyr}$ seems to be missing (Gersonde, 2012). Yellow circles mark published sediment records containing laminated sediments (see Table 1 for details). Dashed lines represent maximum and minimum water depth of the OMZ in the Bering Sea for the last deglaciation based on the occurrence of laminated sediment cores. Note that the deepening of the OMZ down to $3173 \mathrm{~m}$ water depth might be a local phenomenon (see text for details). Transect drawn with Ocean Data View (Schlitzer, 2002).

(Levitus and Boyer, 1994), and are induced by the interplay between the Siberian High and the Aleutian Low (Niebauer, 1980). Surface water masses are influenced by the Alaska Stream (AS), which enters the Bering Sea through several straits between the Aleutian Islands. The surface circulation is characterized by a counterclockwise gyre, formed by the East Kamchatka Current (EKC), the Bering Slope Current (BSC), and the Aleutian Northern Slope Current (ANSC), the lattermost being the link between the inflowing water from the North Pacific and the BSC. The BSC contributes to the northward-flowing Anadyr Current (AC) and feeds the EKC. Surface waters leave the Bering Sea with the southwardflowing EKC to the North Pacific. Deepwater exchange occurs via Kamchatka Strait and Near Strait, but only Kamchatka Strait is deeper than $2000 \mathrm{~m}$ and allows inflow of deep Pacific waters. Modern mid-depth to deep waters (ca. 200-2500 m water depth) within the Bering Sea itself are not well investigated but thought to be rather homogenous in their physical and chemical characteristics and mainly represent a mixture of North Pacific Deep and Intermediate Water (Tsunogai et al., 1979; Luchin et al., 1999). Primary production is high, especially along the edge of the eastern continental shelf and is caused by tidal mixing and transverse circulation, which gave this area the name "Green Belt" (Springer et al., 1996). Biological productivity is dominated by siliceous plankton, with diatoms as major constituents of biogenic opal (Takahashi et al., 2002). Although no persistent mid-depth anoxia exist in the Bering Sea today, an OMZ develops between 900 and $1000 \mathrm{~m}$ water depth (Fig. 2, Garcia et al., 2010). In contrast to other permanent OMZs - e.g., in the eastern North and South Pacific - the one in the Bering Sea exhibits a significant seasonality, with lowest oxygen con- centrations occurring during winter season (Paulmier and Ruiz-Pino, 2009). Throughout the year, oxygen concentrations in the core depth of the OMZ range between 0.4 and $0.7 \mathrm{~mL} \mathrm{~L}^{-1}$ (Garcia et al., 2010).

\section{Material and methods}

\subsection{Sediment records}

During R/V Sonne cruise SO202-INOPEX, 15 sediment cores were recovered from the Bering Sea in 2009 (Fig. 1) on a depth transect from 1066 to $3821 \mathrm{~m}$ water depth (Fig. 2). Of these cores, eight yielded laminated sequences. In this study, we use two cores from an almost identical position: piston core $\mathrm{SO} 202-18-3\left(60^{\circ} 07.60^{\prime} \mathrm{N}, 179^{\circ} 26.67^{\prime} \mathrm{W}\right.$; water depth: $1111 \mathrm{~m} ; 10.5 \mathrm{~cm}$ core diameter) and neighboring kasten core SO202-18-6 $\left(60^{\circ} 07.60^{\prime} \mathrm{N}, 179^{\circ} 26.61^{\prime} \mathrm{W}\right.$; water depth: $1107 \mathrm{~m}, 30 \mathrm{~cm}$ long rectangular sides). Both were retrieved off the large shelf in the northern Bering Sea, and high-resolution echo sound sub-bottom profiling data show that both coring devices penetrated to the same sediment intervals. The sediments consist of diatom-bearing silty to sandy clay. A prominent feature in both cores is the occurrence of several, meter-thick laminated sequences consisting of alternating laminae of lighter pure diatom ooze and darker diatomaceous mud. Also, several ash layers appear in both cores. Detailed core descriptions and sediment echo sounding data from the site are provided in Gersonde (2012). 


\subsection{Geochemical and X-ray image analyses}

In order to obtain high-resolution geochemical data sets of major element composition, non-destructive XRF measurements were performed at the Alfred Wegener Institute with an Avaatech XRF core scanner at $1 \mathrm{~cm}$ resolution for both sediment cores. Each core segment was scanned three times with tube voltages of 10,30 , and $50 \mathrm{kV}$ and counting times of 10,15 , and $30 \mathrm{~s}$, respectively. In a second step, laminated sequences were scanned with up to $200 \mu \mathrm{m}$ resolution at the Leibniz Institute for Baltic Sea Research using an ITRAX core scanner from Cox Analytical Systems and $45 \mathrm{kV}$ Cr-tube voltage and $15 \mathrm{~s}$ counting time. Radiography images on the kasten core were obtained by cutting out $25 \times 10 \times 0.5 \mathrm{~cm}$ sediment slices that were wrapped into plastic foil and sealed vacuum-tight. For the radiographies, we used the cabinet X-ray system Faxitron Series from Hewlett Packard with $40 \mathrm{kV}, 3 \mathrm{~A}$ and 3 min exposure time. For the piston core, X-ray images were taken with the ITRAX core scanner on split sediment surfaces before the XRF scan, with tube voltages between 50 and $60 \mathrm{kV}$, a tube current of $30 \mathrm{~mA}$, and exposure times between 1000 and $1200 \mathrm{~ms}$ depending on the thickness and density of the sediment. The radiographic images from the ITRAX scanner are radiographic positives, in which core segments of lower density appear as light intervals and vice versa (Croudace et al., 2006). Biogenic opal was measured by the sequential leaching method after Müller and Schneider (1993), total carbon content was measured with an Elementar Vario III CNS analyzer, and total organic carbon content with an Eltra CS-2000 Carbon Sulfur element analyzer after removal of carbonate. Sediment samples were also corrected for the pore water salt content (Kuhn, 2013). CaCO3 was calculated as the difference between the former two multiplied by 8.333 .

\subsection{Radiocarbon dating}

For AMS ${ }^{14} \mathrm{C}$ analyses, freeze-dried sediment slices of 2$2.5 \mathrm{~cm}$ thickness were washed over a $63 \mu \mathrm{m}$ mesh-size sieve and dried after washing at $30^{\circ} \mathrm{C}$. At least $1.7 \mathrm{mg}$ of monospecific samples of the planktic foraminifera Neogloboquadrina pachyderma sinistral were picked from the $125-250 \mu \mathrm{m}$ fraction. This foraminifera is a subsurface-dwelling species that lives in the North Pacific between 50 and $200 \mathrm{~m}$ water depth (Kuroyanagi et al., 2002; Bauch et al., 2002). Radiocarbon dating on benthic foraminifera were carried out on mixed benthic, mostly shallow infaunal species (like Uvigerina spp., Elphidium spp, Nonionella spp.; cf. Bubenshchikova et al., 2008) from the fraction $>250 \mu \mathrm{m}$. All radiocarbon measurements were performed by the National Ocean Sciences Accelerator Mass Spectrometry (NOSAMS) facility at the Woods Hole Oceanographic Institution. Ages are reported following established conventions (Stuiver and Polach, 1977). All radiocarbon dates were converted into calendar ages with the calibration software Calib 7.0 (Stu-

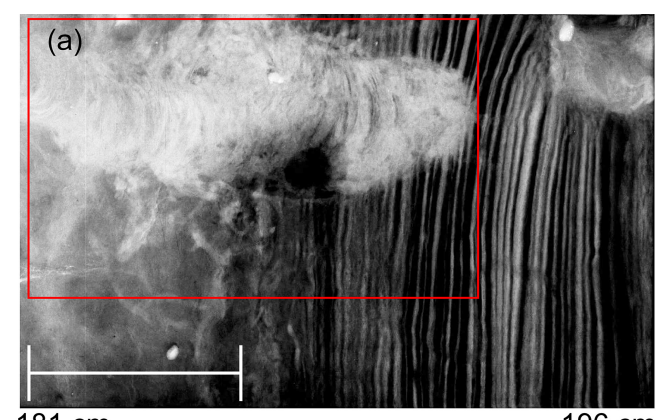

$181 \mathrm{~cm}$

$196 \mathrm{~cm}$
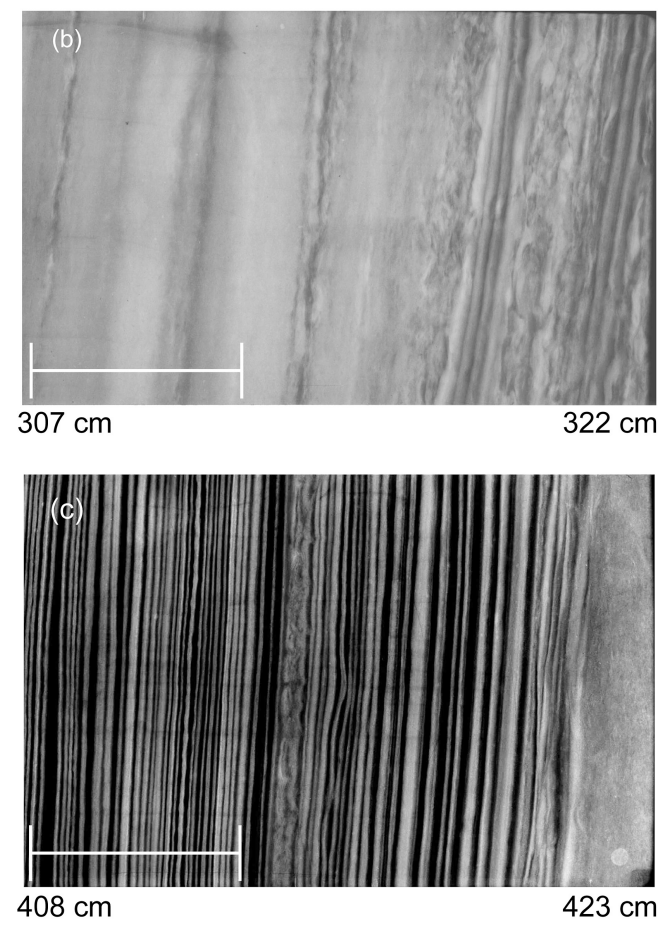

Figure 3. Examples of three different sediment facies in SO202-18-3/6 as shown in radiographs. (a) Bioturbated Facies (left side) and Bioturbated Lamination Facies (middle section) at the end of Preboreal laminations, (b) Layered Facies, and (c) Laminated Facies during the Preboreal. All radiographs are shown with increasing core depth to the right. The core depths of each radiograph sections are indicated below the images. The red box in (a) marks a bioturbational feature that led to an age reversal in a ${ }^{14} \mathrm{C}$ age in core SO202-18-6, 180-182.5 cm. The scale bar on each radiograph marks a $5 \mathrm{~cm}$ interval.

iver and Reimer, 1993) and the INTCAL13 calibration curve (Reimer et al., 2013). For the initial age conversion, a planktic reservoir age of $R=700 \mathrm{yr}$ was chosen, in line with previous works (Max et al., 2012; Rella et al., 2012; Itaki et al., 2009; Cook et al., 2005). Changes in deep-water ventilation ages were derived by calculating benthic-planktic ventilation ages, which are the difference between coeval benthic and planktic foraminiferal ${ }^{14} \mathrm{C}$ ages from the same respective core depth. All AMS ${ }^{14} \mathrm{C}$ measurements and 

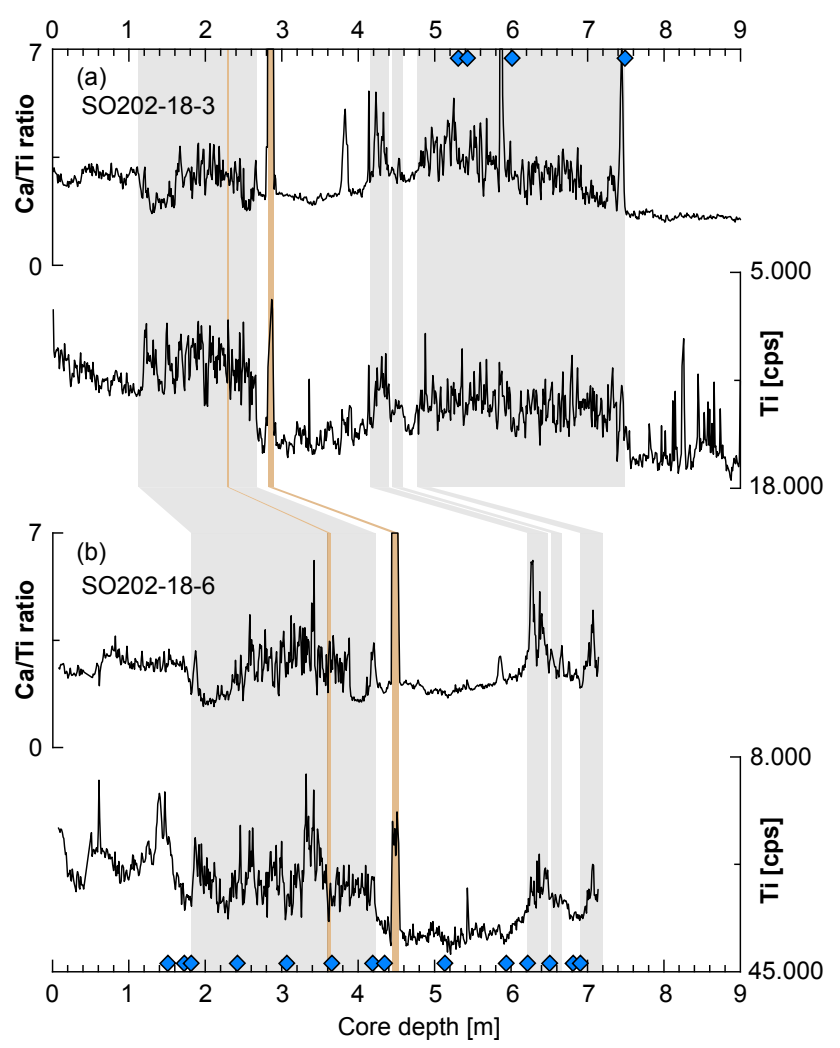

Figure 4. Inter-core correlation between piston core SO202-18-3 (a) and kasten core SO202-18-6 (b) based on XRF-scanning data of the $\mathrm{Ca} / \mathrm{Ti}$ ratio and Ti concentrations (given in counts per second). Gray bars mark the occurrence of Layered and Laminated Facies; brown bars mark ash layers. Note inverse scale of Ti concentrations. Blue diamonds mark planktic AMS ${ }^{14} \mathrm{C}$ ages.

calibration results are provided in Table 2 . One ${ }^{14} \mathrm{C}$ result of the depth interval $180-182.5 \mathrm{~cm}$ in SO202-18-6 was discarded from further analysis, as it shows an age reversal that is likely attributed to a localized, bioturbation feature, which is clearly visible in the X-ray image from this depth interval (cf. Fig. 3a). For our other laminated cores from the Bering Sea an initial age model to determine Termination I was constructed based on correlation of XRF results (Supplement Fig. S1).

\subsection{Sediment classification and laminae counts}

Laminae counts were performed manually on X-ray images, as the single laminae, due to their varying densities, are clearly visible in these images, compared to digital photos of the core surface. In addition, we combined the X-ray images with chlorine $(\mathrm{Cl})$ counts from micro-XRF scans as a proxy for water contents (Tjallingii et al., 2007). These counts responded sensitively to density changes within the different laminae, as light and dark laminae contain different amounts of pore water. The combination of X-ray images and highresolution ITRAX data has been previously used and shown to be a suitable method for laminae countings (e.g., Staff et al., 2012). We always counted couplets of one light and one dark lamina. Laminae counting proceeded until no single laminae were visible anymore in the X-ray images, e.g., through the effect of bioturbation. The deeper laminated sequences were counted on piston core SO202-18-3, as they were not fully recovered in core SO202-18-6. For the upper laminated sections, we concentrated on core SO202-186 , which has a better core quality during this interval. Based on repetitive laminae counts from different core section and by different investigators, the counting error is estimated to be \pm 5 laminae couplets for respective, ca. $1 \mathrm{~m}$ long, laminated sequences. This error estimation is used as counting uncertainties for the prominent laminated units that we identified in our cores (cf. Sect. 4.3). As we do not have a continuous record of laminated sediments, we cannot estimate a cumulative maximum counting error, which increases with depth, as done for the Greenland ice core record (Rasmussen et al., 2006).

For this study, the sediment was classified into four different types of sediment facies: (1) "Laminated Facies", (2) "Layered Facies", (3) "Bioturbated Lamination Facies", and a (4) "Bioturbated Facies". A comparable approach was applied previously in other Pacific locations on laminated sediments from the Santa Barbara Basin (Behl and Kennett, 1996) and the Japan Sea (Watanabe et al., 2007) in order to assign different types of sediment to different oxygen concentrations. The differentiation into these categories was done by visual inspection of the X-ray images (Fig. 3): the Laminated Facies consists of distinct and undisturbed sub-millimeter-scale up to $6 \mathrm{~mm}$ thick laminations with clear boundaries that can be counted and do not show signs of burrowing or other disturbances. In the Layered Facies, boundaries between biogenic and siliciclastic parts of the laminations are not clearly discernible or disappearing and centimeter-thick, undisturbed layers of mostly siliciclastic material are formed instead of clearly alternating sedimentary patterns as in the Laminated Facies. The thickness of these facies in our sediment core ranges from several centimeters down to $1 \mathrm{~cm}$. In the Bioturbated Lamination Facies, originally laminated structure is partially disturbed through burrowing organisms. Lastly, the Bioturbated Facies does not show any traces of laminations or layers, since it has been completely homogenized by benthic organisms.

\section{Results and discussion}

\subsection{Initial ${ }^{14} \mathrm{C}$-supported age model and regional stratigraphic context}

In order to correlate cores SO202-18-3 and SO202-18-6, the occurrence of two distinct ash layers, $\mathrm{Ca} / \mathrm{Ti}$ ratios, and $\mathrm{Ti}$ counts from XRF scanning, as well as the occurrence of the laminated sections, were used (Fig. 4). In the XRF scans the 
Table 2. AMS ${ }^{14} \mathrm{C}$ ages, calibrated calendar ages with $1 \sigma$ ranges, reservoir ages (res. age), and calculated benthic-planktic ventilation ages (ventil. age). Marked bold/italic res. ages are deduced by NGRIP correlation/layer counting. For comparison calendar ages with a constant reservoir age of $R=700 \mathrm{yr}$ are also shown. Nps: Neogloboquadrina pachyderma sinistral; Uvi: Uvigerina spp.; mb: mixed benthic foraminifera.

\begin{tabular}{|c|c|c|c|c|c|c|c|c|c|c|}
\hline Core & $\begin{array}{l}\text { Sample } \\
\text { ID }\end{array}$ & $\begin{array}{l}\text { Depth } \\
(\mathrm{cm})\end{array}$ & Species & $\begin{array}{c}{ }^{14} \mathrm{C} \text { age } \\
(\mathrm{yr})\end{array}$ & $\begin{array}{l}\text { Res. age } \\
(y r)\end{array}$ & $\begin{array}{l}\text { Ventil. ages } \\
(\mathrm{yr})\end{array}$ & $\begin{array}{l}\text { Error ventil. } \\
\text { ages } \pm(\mathrm{yr})\end{array}$ & $\begin{array}{c}\text { Calendar age } \\
(\mathrm{yr})\end{array}$ & $\begin{array}{l}\text { Calendar age } \\
\text { (yr) } 1 \sigma \text { range }\end{array}$ & $\begin{array}{l}\text { Calendar age }(\mathrm{yr}) \\
\text { with } 700 \mathrm{yr} \text { res.age }\end{array}$ \\
\hline \multirow[t]{8}{*}{ SO202-18-3 } & OS-93967 & $530-532$ & Nps & $12600 \pm 50$ & 870 & 650 & 100 & 13539 & $13472-13579$ & 13710 \\
\hline & OS-93973 & $530-532$ & $\mathrm{mb}$ & $13250 \pm 50$ & & & & & & \\
\hline & OS-93968 & $542-544$ & $\mathrm{Nps}$ & $12600 \pm 45$ & 820 & 850 & 100 & 13612 & $13551-13711$ & 13712 \\
\hline & OS-93881 & $542-544$ & $\mathrm{mb}$ & $13450 \pm 55$ & & & & & & \\
\hline & OS-93978 & $601-603$ & $\mathrm{Nps}$ & $12800 \pm 65$ & 730 & 700 & 115 & 13918 & $13809-14005$ & 13954 \\
\hline & OS-93969 & $601-603$ & $\mathrm{mb}$ & $13500 \pm 50$ & & & & & & \\
\hline & OS-92056 & $747.5-750$ & Nps & $13350 \pm 55$ & 880 & 600 & 110 & 14640 & $14419-14856$ & 15049 \\
\hline & OS-92023 & $747.5-750$ & Uvi & $13950 \pm 55$ & & & & & & \\
\hline \multirow[t]{28}{*}{ SO202-18-6 } & OS-96110 & $150-152.5$ & $\mathrm{Nps}$ & $9280 \pm 65$ & 770 & 680 & 115 & 9505 & $9476-9539$ & 9550 \\
\hline & OS-96032 & $150-152.5$ & $\mathrm{mb}$ & $9960 \pm 50$ & & & & & & \\
\hline & OS-93972 & $170-172.5$ & $\mathrm{Nps}$ & $9650 \pm 35$ & 770 & 800 & 85 & 10029 & $9917-10150$ & 10075 \\
\hline & OS-93974 & $170-172.5$ & $\mathrm{mb}$ & $10450 \pm 50$ & & & & & & \\
\hline & OS- $94161^{\mathrm{a}}$ & $180-182.5$ & $\mathrm{Nps}$ & $9520 \pm 80$ & 770 & 1030 & 130 & 9766 & 9604-9890 & 9884 \\
\hline & OS-96033 & $180-182.5$ & $\mathrm{mb}$ & $10550 \pm 50$ & & & & & & \\
\hline & OS-85754 & $240-242.5$ & $\mathrm{Nps}$ & $10050 \pm 25$ & 770 & 450 & 80 & 10476 & $10422-10518$ & 10566 \\
\hline & OS-90768 & $240-242.5$ & $\mathrm{mb}$ & $10500 \pm 55$ & & & & & & \\
\hline & OS-90732 & $305-307.5$ & $\mathrm{Nps}$ & $10450 \pm 40$ & 770 & 600 & 90 & 11126 & $10907-11194$ & 11195 \\
\hline & OS-92014 & $305-307.5$ & $\mathrm{mb}$ & $11050 \pm 50$ & & & & & & \\
\hline & OS-85755 & $364-366.5$ & Nps & $10700 \pm 35$ & 765 & 700 & 80 & 11324 & $11263-11388$ & 11470 \\
\hline & OS-90699 & $364-366.5$ & $\mathrm{mb}$ & $11400 \pm 45$ & & & & & & \\
\hline & OS- $85756^{b}$ & $415-417.5$ & Nps & $10850 \pm 25$ & 775 & 450 & 75 & 11650 & $11506-11750$ & 11828 \\
\hline & OS-90698 & $415-417.5$ & $\mathrm{mb}$ & $11300 \pm 50$ & & & & & & \\
\hline & OS-96111 b & $432-434.5$ & $\mathrm{Nps}$ & $10950 \pm 55$ & 830 & 600 & 115 & 11745 & $11614-11946$ & 11992 \\
\hline & OS-96112 ${ }^{b}$ & $432-434.5$ & $\mathrm{mb}$ & $11550 \pm 60$ & & & & & & \\
\hline & OS- $94120^{b}$ & $512-514.5$ & $\mathrm{Nps}$ & $11150 \pm 65$ & 800 & 650 & 125 & 12210 & $12083-12382$ & 12348 \\
\hline & OS-96034 ${ }^{b}$ & $512-514.5$ & $\mathrm{mb}$ & $11800 \pm 60$ & & & & & & \\
\hline & OS-96095 ${ }^{b}$ & $592-594.5$ & $\mathrm{Nps}$ & $11850 \pm 60$ & 1100 & 450 & 140 & 12685 & $12654-12724$ & 13020 \\
\hline & OS-96035 & $592-594.5$ & $\mathrm{mb}$ & $12300 \pm 80$ & & & & & & \\
\hline & OS-85757 & $622-624.5$ & Nps & $12000 \pm 35$ & 990 & 650 & 100 & 12869 & $12795-12935$ & 13144 \\
\hline & OS-90733 & $622-624.5$ & $\mathrm{mb}$ & $12650 \pm 65$ & & & & & & \\
\hline & OS-85758 & $650-652.5$ & $\mathrm{Nps}$ & $12050 \pm 30$ & 970 & 700 & 75 & 12955 & $12897-13028$ & 13194 \\
\hline & OS-92049 & $650-652.5$ & $\mathrm{mb}$ & $12750 \pm 45$ & & & & & & \\
\hline & OS-96107 & $680-682.5$ & Nps & $12250 \pm 70$ & 860 & 600 & 140 & 13230 & $13150-13293$ & 13384 \\
\hline & OS-96106 & $680-682.5$ & $\mathrm{mb}$ & $12850 \pm 70$ & & & & & & \\
\hline & OS-85759 & $690-692.5$ & $\mathrm{Nps}$ & $12350 \pm 30$ & 880 & 650 & 90 & 13318 & $13274-13353$ & 13483 \\
\hline & OS-92057 & $690-692.5$ & $\mathrm{mb}$ & $13000 \pm 60$ & & & & & & \\
\hline
\end{tabular}

${ }^{\mathrm{a}}$ Age reversal. ${ }^{\mathrm{b}}$ Derived from Max et al. (2014)

laminated and layered sequences in both cores are characterized by higher $\mathrm{Ca} / \mathrm{Ti}$ ratios and lower Ti counts (Fig. 4), with similar peak structure especially in the $\mathrm{Ca} / \mathrm{Ti}$ ratios. Due to the shorter length of the kasten core, the lowermost laminated section was only partly recovered in core SO20218-6. In total, piston core SO202-18-3 contains $461 \mathrm{~cm}$ of low-oxygen sediment sequences (i.e., Laminated and Layered Facies), and kasten core SO202-18-6 about $300 \mathrm{~cm}$. We correlated the onset of laminated and non-laminated sections as basic lithostratigraphic units, by visual inspection and XRF-scanning records between cores SO202-18-3 and SO202-18-6. As an independent correlation marker we used two tephra layers identified in both cores (Table 3 and Gersonde, 2012). This enabled us to transfer ${ }^{14} \mathrm{C}$ ages of core SO202-18-6 to corresponding depths of core SO202-18-3, where the upper part was not sampled. The correlated core depths of core SO202-18-3 are given in Supplement Ta- ble S1. An overview of the different sedimentary facies with according core depths is given in Table 3; the correlation pattern is shown in Fig. 4. Other laminated INOPEX cores from the Bering Sea reveal similar trends in the XRF data (Supplement Fig. S1).

To establish a chronostratigraphic framework for the combined core SO202-18-3/6, we converted the individual planktic AMS ${ }^{14} \mathrm{C}$ ages to calendar ages by using the INTCAL13 calibration curve (Reimer et al., 2013). In this first age control step, we used a constant reservoir age of $R=700 \mathrm{yr}$ (Table 2), in line with most previous studies (Gorbarenko et al., 2005; Itaki et al., 2009; Max et al., 2012). However, marine reservoir ages likely have varied over the glacial termination in the western North Pacific (Sarnthein et al., 2007). We address the potential changes in local reservoir ages in the discussion of Sect. 4.3. An age-depth relationship (Fig. 5) was established by linear interpolation between 


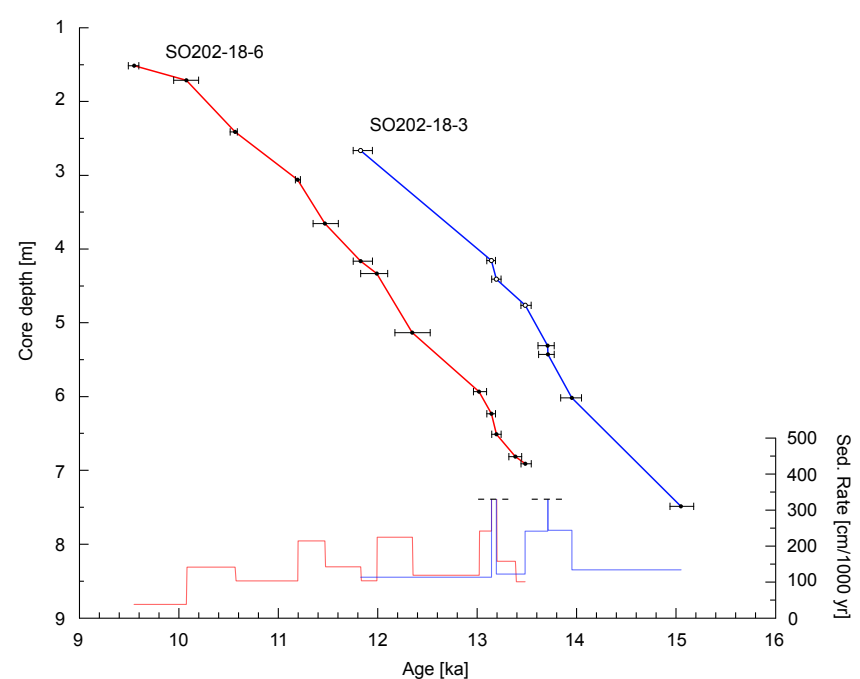

Figure 5. Age-depth relationship of cores SO202-18-3 (blue curve) and SO202-18-6 (red curve) based on use of constant reservoir ages of $700 \mathrm{yr}$. Error bars show $1 \sigma$ ranges of ${ }^{14} \mathrm{C}$ results. White circles in blue curve show ages derived by core-to-core correlation. Light red and blue curves show sedimentation rates. Note the cut-off in the

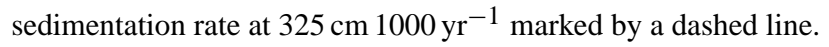

individual planktic AMS ${ }^{14} \mathrm{C}$ age control points through their reported median probability ages (Telford et al., 2004). According to this age model, linear sedimentation rates mostly range between 150 and $250 \mathrm{~cm} \mathrm{ka}^{-1}$.

To incorporate the radiocarbon-based age model of our sediment record into an established regional stratigraphic framework for the last deglaciation, we used calcium carbonate concentrations, represented by Ca XRF counts in our records and compared those with earlier published sediment records. Deglacial sediment sequences in the North Pacific region are characterized by the occurrence of two prominent calcium carbonate peaks that have been radiocarbon-dated and assigned to glacial terminations $\mathrm{Ia}$ and $\mathrm{Ib}$ in the open North Pacific (Keigwin et al., 1992; Galbraith et al., 2007), the Bering Sea (Gorbarenko et al., 2005), and the Okhotsk Sea (Keigwin, 1998; Max et al., 2012). Our Ca concentration records closely correspond to previously published carbonate data (Itaki et al., 2009; Max et al., 2012; Rella et al., 2012). In those studies, following other published records (Cook et al., 2005; Kim et al., 2011; Schlung et al., 2013), the lower laminated sequence was assigned to the BøllingAllerød interstadial, whereas the upper laminated interval was identified to represent the early Holocene. In particular, the 11-point smoothed $\mathrm{Ca}$ counts curve of core SO20218-3 (Fig. 6a) closely resembles the lower-resolved $\mathrm{CaCO}_{3}$ record of nearby core PC23A (Fig. 6b, Itaki et al., 2009; Rella et al., 2012) in the laminated intervals, with similar peak structures. The corresponding uncorrected AMS ${ }^{14} \mathrm{C}$ ages of planktic foraminifera measured on the individual carbonate peaks in SO202-18-3 and SO202-18-6 are nearly
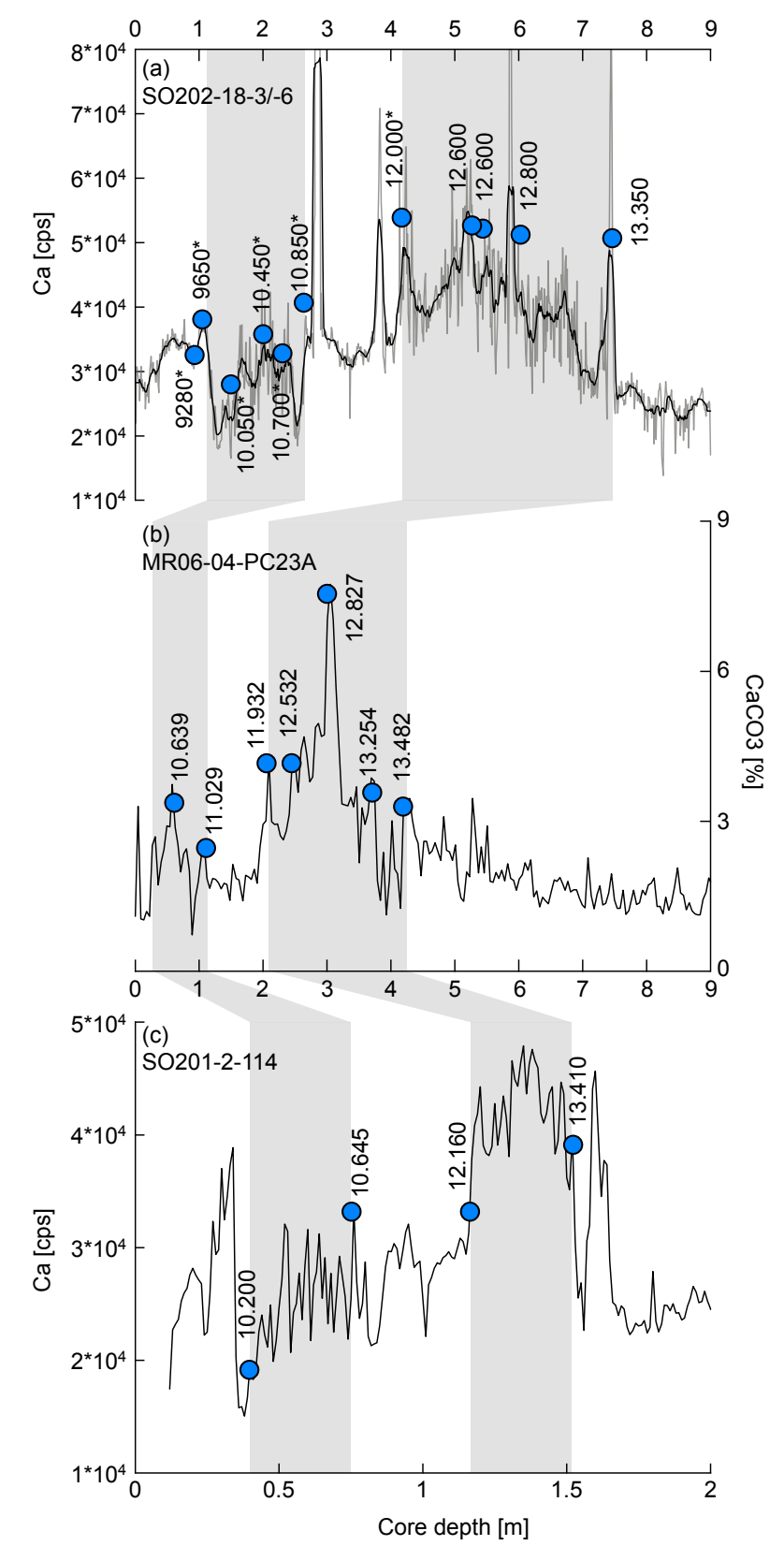

Figure 6. Regional stratigraphic framework based on established basin-wide carbonate peak patterns (Max et al., 2012; Keigwin et al., 1992). Comparison of core SO202-18-3 (this study) to published Bering Sea records with radiocarbon age control and laminated sediment sections. (a) Ca XRF counts of SO202-18-3; thick black line shows the 11-point moving average of the Ca data. ${ }^{14} \mathrm{C}$ ages in this graph marked with asterisks are from SO202-18-6 and were transferred to the corresponding depths of SO202-18-3 through corecore correlation. One ${ }^{14} \mathrm{C}$ age is not plotted, as it shows an age reversal (see text for details). (b) Core MR06-04-PC23A (Itaki et al., 2009; Rella et al., 2012). (c) Core SO201-2-114 (Max et al., 2012). Blue circles denote radiocarbon dates age with raw, uncalibrated ${ }^{14} \mathrm{C}$ ages. Gray shading indicates anoxic (laminated/layered) core sections. 
Table 3. Core depths of the different facies types occurring in cores SO202-18-3 and SO202-18-6: lam: Laminated Facies; lay: Layered Facies; biolam: Bioturbated Lamination Facies; bio: Bioturbated Facies; ash: ash layer. Depth intervals of prominent laminated units (TIBLU1-5) are marked bold/italic.

\begin{tabular}{|c|c|c|c|c|c|}
\hline Core & Depth $(\mathrm{cm})$ & Facies & Core & Depth (cm) & Facies \\
\hline \multirow[t]{56}{*}{ SO202-18-3 } & $0-111.82$ & bio & SO202-18-6 & $0-183.91$ & bio \\
\hline & $111.82-120.07$ & biolam & & $183.91-191.84$ & biolam \\
\hline & $120.07-125.52$ & lam & & $191.84-193.5$ & lam \\
\hline & $125.52-126.6$ & lay & & $193.5-208.57$ & biolam \\
\hline & $126.6-128.31$ & lam & & $208.57-214$ & lam \\
\hline & $128.31-132.57$ & lay & & $214-256.42$ & lay \\
\hline & $132.57-137.1$ & lam & & $256.42-258.49$ & lam \\
\hline & $137.7-157.45$ & lay & & 258.49-261.04 & lay \\
\hline & $157.45-159.62$ & lam & & 261.04-263.09 & lam \\
\hline & $159.62-163.47$ & lay & & $263.09-269.33$ & lay \\
\hline & $163.47-169.37$ & lam & & $269.33-270.18$ & lam \\
\hline & $169.37-173.4$ & lay & & $270.18-280.83$ & lay \\
\hline & $173.4-174.28$ & lam & & $280.83-300.33$ & lam \\
\hline & $174.28-180.66$ & lay & & $300.33-317.67$ & lay \\
\hline & $180.66-196.91$ & lam & & $317.67-322$ & lam \\
\hline & $196.91-200.62$ & lay & & $322-324.84$ & lay \\
\hline & $200.62-201.99$ & lam & & $324.84-360.25$ & lam \\
\hline & 201.99-203.92 & lay & & $360.25-362.49$ & ash \\
\hline & 203.92-226.7 & lam & & $362.49-421.05$ & lam \\
\hline & 226.7-231.39 & ash & & $421.05-448$ & bio \\
\hline & $231.39-266.27$ & lam & & $448-453.57$ & ash \\
\hline & $266.27-282.2$ & bio & & $453.57-620.02$ & bio \\
\hline & $282.2-287.5$ & ash & & $620.02-629.85$ & biolam \\
\hline & $287.5-415.75$ & bio & & $629.85-647.39$ & lam \\
\hline & $415.75-421.18$ & biolam & & $647.39-651.74$ & bio \\
\hline & $421.18-423.43$ & lam & & $651.74-665.68$ & biolam \\
\hline & $423.43-424.89$ & lay & & $665.68-690.75$ & bio \\
\hline & $424.89-440.78$ & lam & & $690.75-698.8$ & biolam \\
\hline & $440.78-444.08$ & bio & & $698.8-725$ & lam \\
\hline & $444.08-458.83$ & biolam & & & \\
\hline & $458.83-476.15$ & bio & & & \\
\hline & $476.15-483.59$ & biolam & & & \\
\hline & 483.59-503.4 & lam & & & \\
\hline & $503.4-504.52$ & lay & & & \\
\hline & $504.52-509.7$ & lam & & & \\
\hline & $509.7-510.36$ & lay & & & \\
\hline & $510.36-527.42$ & lam & & & \\
\hline & $527.42-528.85$ & lay & & & \\
\hline & $528.85-532.46$ & lam & & & \\
\hline & $532.46-533.48$ & lay & & & \\
\hline & $533.48-535.33$ & lam & & & \\
\hline & $535.33-536$ & lay & & & \\
\hline & $536-538.5$ & lam & & & \\
\hline & $538.5-540.73$ & lay & & & \\
\hline & $540.73-542.72$ & lam & & & \\
\hline & $542.72-543.84$ & lay & & & \\
\hline & $543.84-561.75$ & lam & & & \\
\hline & $561.75-563.2$ & lay & & & \\
\hline & $563.2-580.76$ & lam & & & \\
\hline & $\mathbf{5 8 0 . 7 6 - 5 8 1 . 7 7}$ & lay & & & \\
\hline & $581.77-602.81$ & lam & & & \\
\hline & $602.81-608.87$ & lay & & & \\
\hline & $608.87-615.45$ & lam & & & \\
\hline & $615.45-618.16$ & lay & & & \\
\hline & $618.16-747.08$ & lam & & & \\
\hline & $747.08-1849$ & bio & & & \\
\hline
\end{tabular}




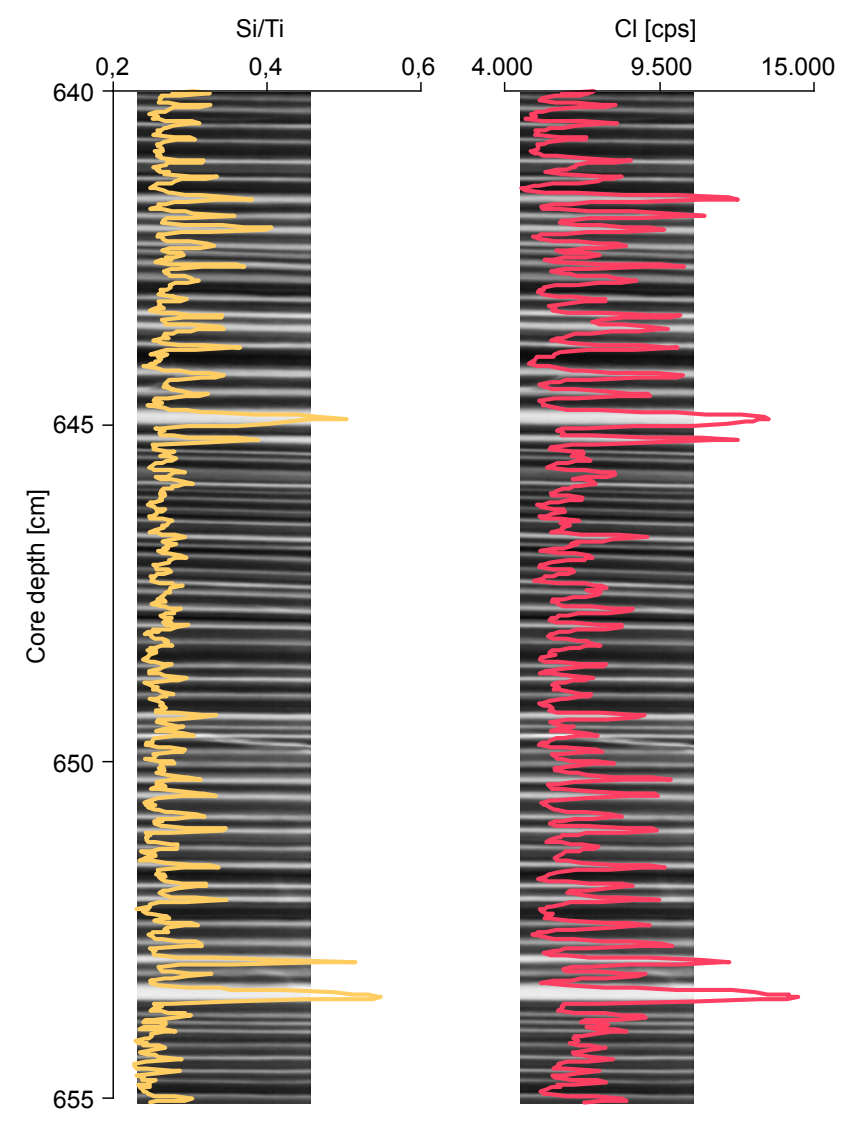

Figure 7. Example micro-XRF $\mathrm{Si} / \mathrm{Ti}$ and $\mathrm{Cl}$ counts and $\mathrm{X}$-ray images of SO202-18-3, 640-655 cm core depth. Note that less dense laminae are shown in white. The white laminae with high amounts of well-preserved diatoms represent the spring/summer bloom, while the dark, denser laminae contain high amounts of terrigenous material.

identical to those dated in core PC23A, i.e., mostly differing by less than $100{ }^{14} \mathrm{C}$ yr. Though it is less densely dated, core SO201-2-114 with laminated sediment sections from the western Bering Sea margin (Max et al., 2012) also closely matches our carbonate peak pattern and uncorrected ${ }^{14} \mathrm{C}$ ages (Fig. 6c).

The observed close similarities between the cores of this study and previously published records give us confidence to assign our Laminated and Layered Facies sections to the deglacial phases of the Bølling-Allerød and Preboreal, and the bioturbated intermediary sediment sections to the Younger Dryas (GS-1) interval. Based on this assumption we progressed to subsequent laminae counts and analyses, in order to assess the nature of deglacial and Preboreal anoxia occurrences on the Bering Sea margin and their temporal relationship with regional ocean proxy time series and the NGRIP ice core reference record (NGRIP-Members et al., 2004).

The comparison to other laminated sediment cores from the Bering Sea also reveals that the OMZ expanded to greater water depths, as sediment cores that lie below the lower boundary of the modern moderate OMZ of $900 \mathrm{~m}$ water depth show laminations during the last deglaciation (Fig. 2). The maximum vertical expansion of the OMZ according to the lamination occurrence in sediment cores extended from $818 \mathrm{~m}$ (laminated core U1342; Takahashi et al., 2011) to a maximum of $3173 \mathrm{~m}$ (laminated core U1344; Takahashi et al., 2011). However, such deep expansion of the deglacial OMZ might be a localized phenomenon of the core U1344 site, as a comparable depth was not recorded as laminated in cores retrieved during the INOPEX cruise. There, the deepest laminated cores are from $2109 \mathrm{~m}$ (SO202-12), during the last deglaciation (Figs. 1, 2; Gersonde, 2012).

\subsection{Core site lamination pattern based on XRF and $\mathrm{X}$-ray results}

The micro-XRF data and radiographs reveal that the laminae of pure diatom ooze have a lower density due to the high concentration of well-preserved diatoms. This also leads to higher $\mathrm{Si} / \mathrm{Ti}$ ratios and $\mathrm{Cl}$ counts (Fig. 7), the latter being the effect of the high porosity of the material and thus higher pore water content. Through the effect of dilution, the diatom-rich laminated sequences also lead to generally lower Ti counts within these intervals (Fig. 4). Microscopic analyses of selected smear slides from both cores indicate that $\mathrm{Si}$ rich laminae comprise well-preserved diatom species such as Fragilariopsis oceanica, F. cylindrus, Bacterosira bathyomphala and Porosira glacialis, which are sea-ice- or coldwater-related species in the modern Bering Sea (Fig. S2; Ren et al., 2014). Preliminary diatom countings revealed concentrations of up to $76 \%$ for the sea-ice-related diatoms $F$. oceanica and F. cylindrus in the diatom species assemblages of these laminae. Detailed counting results of selected smear slides are given in Supplement Table S2. Phytoplankton blooms at ice edges during spring are common in the Bering Sea today (Niebauer and Alexander, 1985). Accordingly, we interpret the Si-rich layers as diatom-productivitydominated time intervals related to the spring/summer sea ice break-up phase, whereas their denser counterparts are lower in biogenic Si and contain relatively large amounts of terrigenous detrital material, rather reflecting the autumn/winter sedimentation.

The X-ray images further reveal that the transition from bioturbated sediment to laminations occurs abruptly, especially at the Younger Dryas-Holocene transition in both cores and at the onset of the Bølling in core SO202-18-3. However, traces of bioturbation can reach several centimeters downcore at the transition from laminated to bioturbated sediment (Fig. 3a). According to our sediment analysis there are repeated, thicker intervals of laminated sediment sequences in our cores. We call these "Termination I Bering Sea Lamination Units" with consecutive numbering from the younger to older sequences (TI-BLU1-5). In core SO202-18-3, TI-BLU3-5 are separated by thinner sediment 


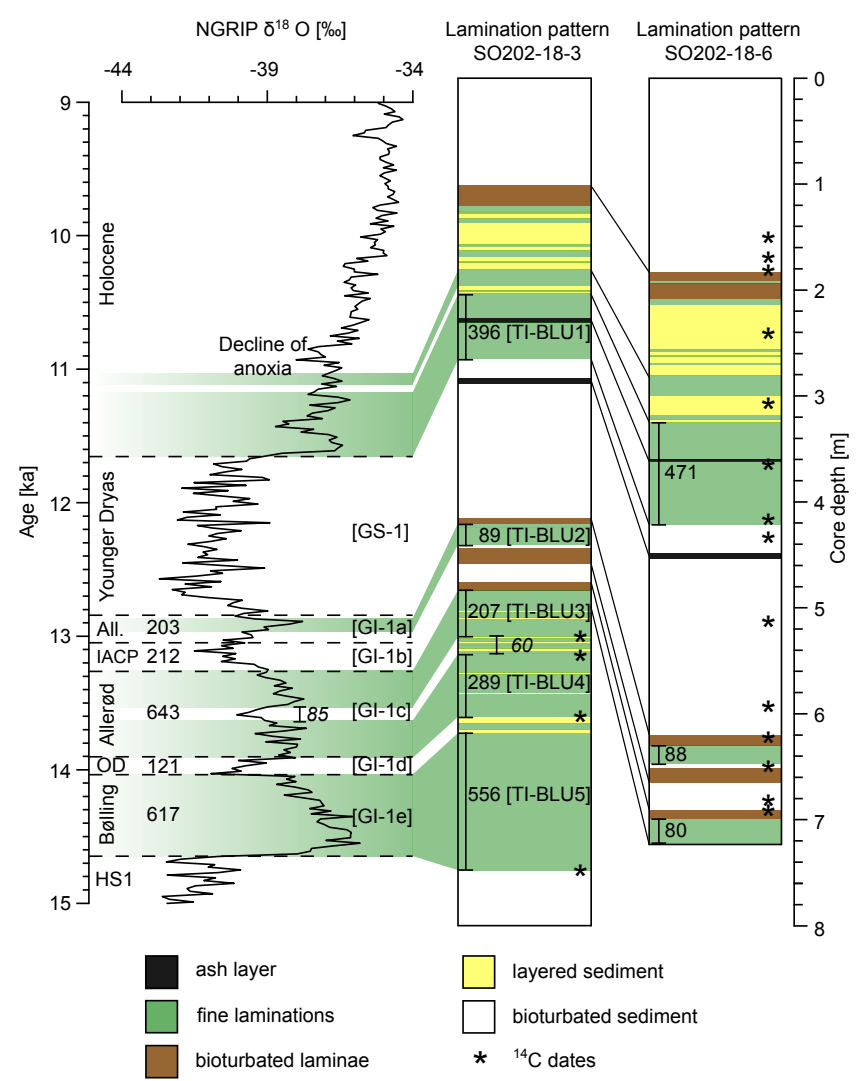

Figure 8. Correlation between lamination pattern in cores SO202-18-3/6 to $20 \mathrm{yr}$ average NGRIP ice core data (Rasmussen et al., 2006). Dashed lines and captions on the right side of NGRIP data mark the events according to the GICC05 chronology, and their duration is given with the numerical numbers between the dashed lines. The left side of the stable isotope graph shows the commonly used terminology of the Blytt-Sernander sequence (Mangerud et al., 1974) for comparison. The italic number inside GI-1c gives the duration of a short cold period inside the Allerød that we also identified in our core SO202-18-3. Green colors in the NGRIP data mark warm phases that correspond to the laminated sediment intervals of our sediment cores. On the right side the lamination patterns of SO202-18-3 and SO202-18-6 are shown. Bioturbated Facies are shown in white, Bioturbated Lamination Facies in brown, Layered Facies in yellow, Laminated Facies in green, and ash layers in black. Black lines between both cores mark correlated sediment facies. Laminated sections that were correlated with warm periods in the ice core record are labeled TI-BLU1-5. Asterisk mark ${ }^{14} \mathrm{C}$ dates, and numbers and vertical black lines inside the lamination patterns give results of laminae counts for the TI-BLU intervals. Additionally, laminae countings of a short cold period between TI-BLU4 and TI-BLU3 that was identified during our correlation are given in italic letters (see text for details). Note that thick laminated sections do not occur after $11 \mathrm{ka}$. (All.): Allerød; (IACP): Intra-Allerød Cold Period; (HS1): Heinrich Stadial I; (OD): Older Dryas.

sequences containing additional Layered Facies sediments, while the Bioturbated Laminae Facies as well as the Bioturbated Facies intermittently occur in both cores between
TI-BLU1 and TI-BLU3 (Fig. 8). Small intervals of laminated sediments occur also above TI-BLU1; however we did not include those parts as separately numbered units in the deglacial terminology presented here. At the current stage, we decided to concentrate our efforts on the deglacial section of our record.

\subsection{A floating laminae-counted chronology anchored to the NGRIP $\delta^{18} O$ time series}

Based on our initially established radiocarbon-anchored and regionally correlated stratigraphic framework for site SO202-18-3/6, we performed a detailed counting of the lamination pattern in the deglacial section of site SO202-18-3/6, assuming one laminae couplet represents 1 year of deposition. Following this assumption we refer to a laminae couplet as a "varve" hereafter. We compared the occurrences of the identified five TI-BLU sections, and the number of varves counted therein, to the NGRIP oxygen stable isotope record ( $20 \mathrm{yr}$ resolution) as a Northern Hemisphere climatic reference record. For this exercise, we used two anchor dates for the marine-ice-core correlation: (1) the onset of laminations (TI-BLU5) at the start of the Bølling (or GI-1e) and (2) the re-establishment of laminations at the Younger DryasHolocene boundary (onset TI-BLU1). In addition, we follow the established assumption that laminated sediments correspond to the warmest interstadial phases (e.g., Behl and Kennett, 1996; Rella et al., 2012). In contrast, layered and bioturbated sediments correspond to colder periods.

The results of the varve counts in the sections TI-BLU15 are illustrated in Fig. 8. Our observed alternation of laminated TI-BLU intervals and Layered or Bioturbated Facies sections closely resemble submillennial-scale warm-cold oscillation originally identified in the Greenland ice core $\delta^{18} \mathrm{O}$ record and described in the deglacial chronology by the INTIMATE working group (Rasmussen et al., 2006; Blockley et al., 2011). The number of counted varves seemingly corresponds to time intervals that lie above a certain minimum in the $\delta^{18}$ O NGRIP data of around 39\%o (Fig. 8). In the following, we compared our deglacial time series of Bering Sea events with the respective Greenland sequence of events (GI1e to GS-1/Holocene). From the older towards the younger section of our cores we counted the following intervals.

Section TI-BLU5 consists of $556 \pm 6$ varves. Based on our defined first chronostratigraphic anchor point, these TIBLU5 varves correspond to the Bølling (GI-1e, Fig. 8), which comprises $617 \mathrm{yr}$ on the GICC05 timescale. This ca. $90 \%$ temporal coverage argues for the occurrence of annually deposited, laminated sediments at our site. Based on the assessment that cold intervals are not laminated, the following mainly Layered Facies section between TI-BLU5 and TIBLU4 would then be assigned to the small cooling of the Older Dryas (GI-1d) in the GICC05 chronology.

Section TI-BLU4 consists of $289 \pm 3$ varves and correlates to a first warm phase in the NGRIP Allerød (GI- 


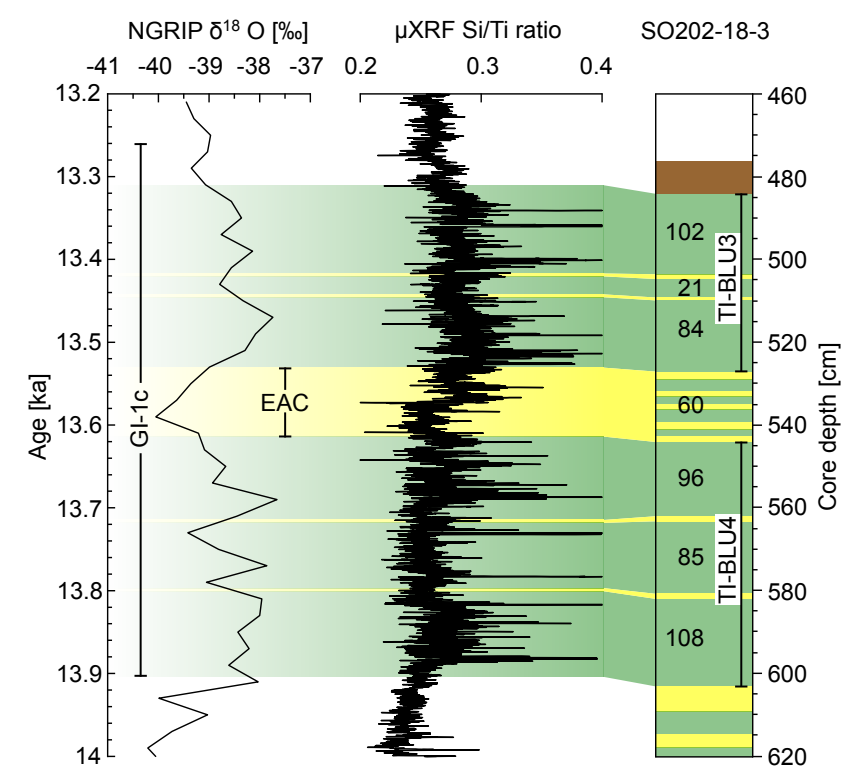

Figure 9. Detailed lamination pattern of core SO202-18-3 covering the Allerød (GI-1c) interval with a correlation with NGRIP ice core data. Left panel: NGRIP $20 \mathrm{yr}$ average $\delta^{18} \mathrm{O}$ record. EAC marks the "Early Allerød Cooling", a small cooling event not named in the GICC05 chronology. Middle panel: micro-XRF Si/Ti ratios as a proxy for productivity, with higher ratios indicative of higher productivity. Right panel: Bering Sea lamination pattern with varve counts. Bioturbated Facies is shown in white, Bioturbated Lamination Facies in brown, Layered Facies in yellow, and Laminated Facies in green as in Fig. 8.

1c), ranging from 13.90 to $13.62 \mathrm{ka}$, thus indicating a nearly complete overlap with our laminae counts. While no formal subdivision has been established within the Allerød (GI-1c) so far (e.g., by the INTIMATE working group; Blockley et al., 2011), we partition this time interval as we can identify short cold periods within this warm phase, which are imprinted as Layered Facies intersections in otherwise Laminated Facies parts in our core and can be correlated with short cold spells in the $20 \mathrm{yr}$ averaged NGRIP $\delta^{18} \mathrm{O}$ time series. The following sequence between TI-BLU4 and TI-BLU3 contains several Layered Facies intervals and is assigned to a short, intra-GI-1c cooling period in the NGRIP $\delta^{18} \mathrm{O}$ record that lasts about $85 \mathrm{yr}(13.62-13.53 \mathrm{ka})$ and which we tentatively call Early Allerød Cooling (EAC, Fig. 9). Despite the intermittent accumulation of Layered Facies sediments within the EAC, we counted $60 \pm 1$ varves and thus cover $80 \%$ of the potential reference time. The detailed inspection of TI-BLU4 before the EAC and TI-BLU3 after the EAC reveals that these two intervals are both interrupted by multiple, thin (i.e., less than $2 \mathrm{~cm}$ thick) Layered Facies sediment sections at ca. 13.80, 13.72, 13.44, and $13.42 \mathrm{ka}$ (Fig. 9). Based on our varve counts these short intervals correspond to rapid, inter-decadal cooling intervals in GI-1c with durations of less than $60 \mathrm{yr}$ each. This lamination pattern is surprisingly similar to the distant NGRIP record, in particular with regard to the bidecadal resolution of the ice core record's $\delta^{18} \mathrm{O}$ time series. This might also be a reason for the slight differences between the temperatures decreases in NGRIP and the position of these thin Layered Facies sections.

Within the uppermost part of interval TI-BLU3 (Fig. 8) the effect of downward bioturbation slightly decreases the precision of laminae counts. In total, $207 \pm 2$ varves were counted in this interval. However, when correlated with the upper part of the Allerød (GI-1c), ranging from 13.53 to $13.26 \mathrm{ka}$, our counts still cover more than $77 \%$ of the NGRIP reference time interval under an annual deposition scenario. We acknowledge that varves might have been lost in the counting process due to the upper completely bioturbated boundary. The cold period on top of TI-BLU3 matches the entire IntraAllerød Cold Period, or IACP (GI-1b). This colder interval in its youngest part shows the first Bioturbated Facies sediments and a short interval of Bioturbated Laminae Facies.

Thereafter, the Laminated Facies section begins, identified as TI-BLU2 (Fig. 8). We counted $89( \pm 1)$ varves in this section and assigned these to NGRIP Allerød (GI-1a). Compared to the GICC05 chronology that provides a duration of $203 \pm 71 \mathrm{yr}$ for this time interval, our TI-BLU2 section is at face value lacking a considerable part of preserved laminae, or years. To resolve this discrepancy, we consider the following explanation: the TI-BLU2 interval is bound both on the upper and lower boundary by intervals with the Bioturbated Laminae Facies, which we were not able to count reliably. Thus, we presume that our reported varve counts in TI-BLU2 are skewed towards lower numbers than have been deposited originally. In fact, for a "true" count of all originally deposited varves, we would have to add the neighboring upper and lower core intervals of the Bioturbated Laminae Facies (5.43 and $18.75 \mathrm{~cm}$, respectively; cf. Table 3) to our counts in the Laminated Facies section $(18.13 \mathrm{~cm}$, Table 3 , all values taken from core SO202-18-3). If we roughly extrapolated the potential number of "uncounted varves" from these Bioturbated Laminae Facies based on core depths and average sedimentation rate/thickness of laminae within the Laminated Facies, we would have to add ca. $119 \pm 12$ varves to our counted 89 varves (in depth interval 421.18-440.78 $\mathrm{cm}$, Table 3, core SO202-18-3), thus bringing the total of originally deposited varves to $208 \pm 13$. This value would then be in excellent agreement with the GICC05-based duration of $203 \mathrm{yr}$ for GI-1a. As a result, we are rather confident that the proposed annual sedimentation regime for the laminae persisted throughout the entire warm phases of the Bølling-Allerød (GI-1). Moreover, a potentially slightly diachronous GS-1 inception as shown by differing proxy time series within the NGRIP ice core might hamper a direct annual one-to-one correlation in this particular time interval (e.g., Ruth et al., 2007; Steffensen et al., 2008). The subsequent interval between TI-BLU2 and TI-BLU1 corresponds to the Younger Dryas (GS-1), and the occurrence of the Bio- 
turbated Facies during this cold interval prevented laminae counts.

For the onset of TI-BLU1 we assume an age of $11.65 \mathrm{ka}$, based on the GICC05 chronology (Fig. 8), in line with our defined anchor point. For TI-BLU1 (11.65-11.18 ka) we, unfortunately, cannot establish a clear upper chronostratigraphic boundary, because cold and warm oscillations identified in the NGRIP ice core during the Preboreal are at present difficult to reconcile with our Bering Sea time series (Fig. 8). We note, however, that neither are all early Holocene climatic oscillations unambiguously recorded in all Greenland ice cores (Rasmussen et al., 2007). Thus, we defined the upper end of TI-BLU1 through laminae counts with a total number of $471 \pm 4$ varves (Fig. 8).

Taken together, our laminae counts show strong support for the hypothesis that laminae are deposited annually. As a result, our achieved correlation allows for the defining of sections which are directly tied to GICC05-derived calendar ages. These independent calendar ages deduced by correlation with the NGRIP record can in turn be used to estimate regional surface reservoir ages (i.e., $R$ ) for radiocarbon dating (Table 2). Our calculated reservoir ages range within 730-990 yr in the Bølling-Allerød (mean reservoir age: $875 \mathrm{yr}$ ), $800-1100 \mathrm{yr}$ in the Younger Dryas (mean reservoir age: $910 \mathrm{yr}$ ) and $765-775 \mathrm{yr}$ in the Preboreal (mean reservoir age: $770 \mathrm{yr}$ ) (cf. Table 2 , directly calculated $R$ values in bold/italic letters). These are qualitatively consistent with earlier studies that suggested varying reservoir ages in the North Pacific during the last deglaciation (Gebhardt et al., 2008; Sarnthein et al., 2007). Our calculated values for local reservoir ages are in line with studies that inferred surface reservoir ages close to $730 \mathrm{yr}$ during the last deglaciation, with variations of about $\pm 200 \mathrm{yr}$ in the eastern North Pacific (Lund et al., 2011), and with reservoir age estimates of 700-800 yr for the British Columbia coast (Southon and Fedje, 2003). However, we note that regional reservoir ages reconstructed for the eastern North Pacific and wester North Pacific during the Bølling-Allerød (GI-1) derived by the "plateau tuning method" (Sarnthein et al., 2007) are younger than our results - with 440 and $720 \mathrm{yr}$, respectively - pointing to the possibility of distinct regional or even localized oceanographic reorganizations in the upper and mid-depth water column during the last deglaciation (Sarnthein et al., 2013).

\subsection{Teleconnections and forcing mechanisms for rapid climate signal transfer}

As a result of the close correspondence between the counted lamination patterns and the Greenland ice core data (Figs. 8, 9), we assume that the preservation of laminations is tied to warm surface temperature intervals concomitant with higher export production, superimposed on the already-warm background temperature within GI-1. This co-occurrence of higher export production with warmer temperatures is also

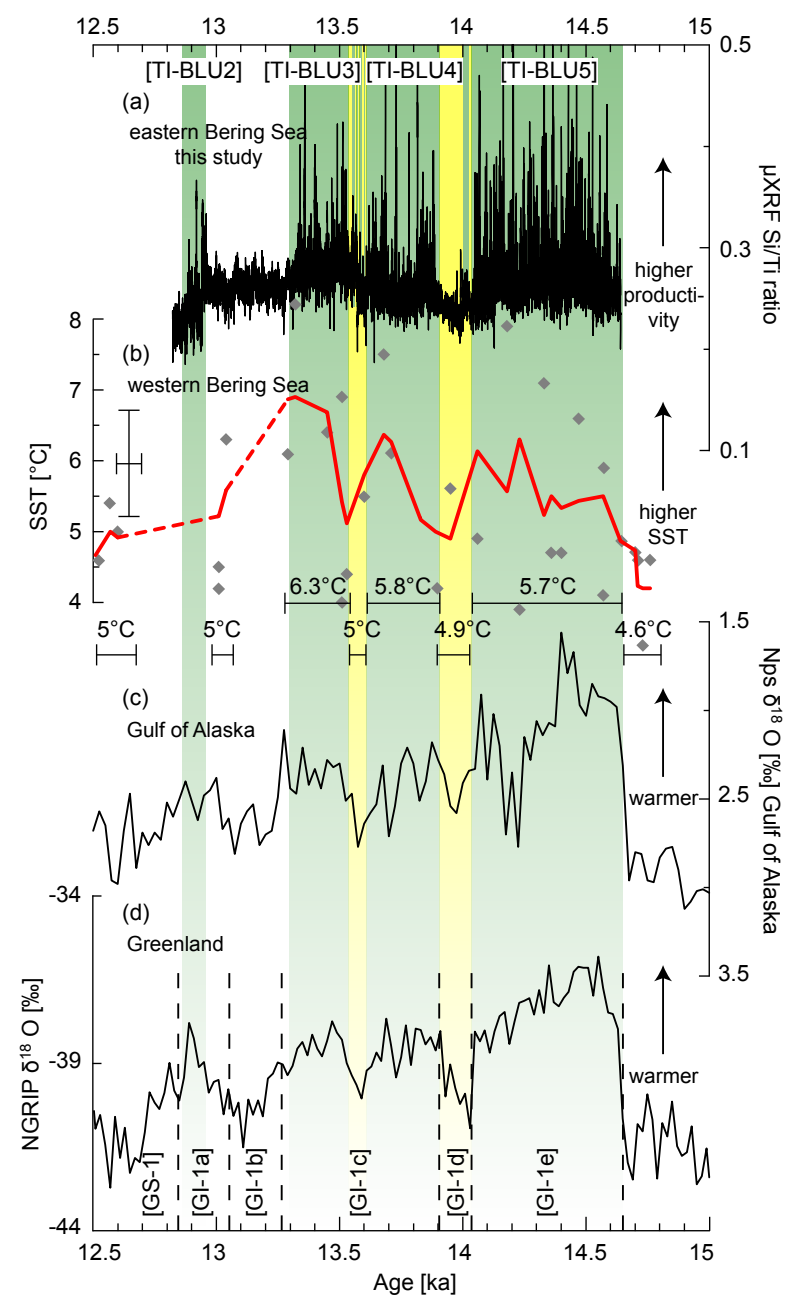

Figure 10. Comparison of laminated core SO202-18-3 with Bering Sea SST records, planktic $\delta^{18} \mathrm{O}$ data from the Gulf of Alaska, and Greenland temperature changes across the Bølling-Allerød time interval. (a) Micro-XRF Si / Ti ratios of SO202-18-3. (b) In red the stacked SST record (three-point running mean) of cores SO2012-77, SO201-2-2-85, and SO201-2-101 from the Shirshov Ridge, western Bering Sea. The gray squares depict the individual SST measurements (Max et al., 2012). Dashed parts in the SST record indicate intervals with insufficient temperature data. The age model used in this plot is the published model of Max et al. (2012). The numerical temperatures below graph (b) are the calculated mean SSTs from the marked warm and cold intervals, and the horizontal bars indicate the temporal range of the average SST. The error bars on the left side of (b) show the uncertainties of SST measurements and radiocarbon datings. (c) $\delta^{18} \mathrm{O}$ data of planktic foraminifera Neogloboquadrina pachyderma sinistral from the Gulf of Alaska as a proxy of long-term changes in annual average SST (Praetorius and Mix, 2014). Note that we used the age model after Praetorius and Mix (2014). (d) NGRIP stable isotope data as reference record. The occurrence of mainly Laminated Facies, Layered Facies, and Bioturbated Facies in SO202-18-3 is shown in green, yellow, and white, respectively. Laminated sections in SO202-18-3 are labeled TI-BLU as in the text. 
evident on decadal timescales by a slight decline of the $\mathrm{Si} / \mathrm{Ti}$ ratios in our proposed EAC (Fig. 9) and on centennial scales during the Older Dryas (GI-1d) and IACP (GI-1b; Fig. 10a). The $\mathrm{Si} / \mathrm{Ti}$ ratios are robust indicators of bio-siliceous export production, as they are not susceptible to post-depositional alteration by sedimentary redox conditions.

To further test the relationship between lamination occurrence and SST, we used lower-resolved alkenone-based SST reconstructions of three cores from the Shirshov Ridge in the western Bering Sea (Max et al., 2012) to infer SST information at least on a basin scale. We used these SSTs as no data are available directly from Laminated and Layered Facies sediment intervals of our sites. We are aware that the alkenone data may represent a seasonal signal, most likely a summer temperature signal (Seki et al., 2007). We merged the individual site reconstructions presented in Max et al. (2012) into one stacked, three-point running mean SST record (Fig. 10b) to consolidate the regional signal. Hereby, we used the published age model of Max et al. (2012). This age model is mainly based on high-resolution scans of color $\mathrm{b}^{*}$ values, a proven proxy for biogenic productivity variations (Nürnberg and Tiedemann, 2004). The close correlation between high color $b^{*}$ values and lamination occurrence during the last deglaciation was also shown for nearby core PC23A (Kim et al., 2011). The standard error of the originally used SST calibration is $\pm 1.5^{\circ} \mathrm{C}$ (Max et al., 2012). Despite the lower resolution, these SST data indicate corresponding temperature variations throughout the Bølling-Allerød (GI-1), and SST maxima broadly correlate with the occurrence of laminated intervals and warmer Greenland air temperatures. The stacked SST record from the Bølling-Allerød (GI-1) reveals temperature differences between the cold phases of the Older Dryas (GI-1d), the small EAC as well as the IACP (GI-1b), and the warm laminated periods. Mean SSTs during the colder Bølling-Allerød intervals in the Bering Sea were around $5^{\circ} \mathrm{C}$, and increased to $6^{\circ} \mathrm{C}$ in the warmer phases (Fig. 10b). Further support comes from a stacked $\delta^{18} \mathrm{O}$ record of the planktic foraminifera Neogloboquadrina pachyderma sinistral of the Gulf of Alaska (GoA), which was interpreted as a proxy for changes of annual SSTs (Fig. 10c; Praetorius and Mix, 2014). This record with decadal-scale resolution clearly shows the warm-cold oscillations during the BøllingAllerød (GI-1) that are visible in our lamination sequence and in the NGRIP record (Fig. 10d). We observe a close correspondence between the GoA and our Bering Sea record even for short-term events like the observed EAC event, reflected in higher $\delta^{18} \mathrm{O}$ GoA values (i.e., lower SSTs). These temperature trends from several locations in the North Pacific in principle support our assumption that anoxia occurrence is connected to warmer SSTs; however, additional annually resolved SST proxy time series from our sites would be needed to prove a causal relationship between higher SSTs and the occurrence of anoxia.

The clear imprint of even such short time periods like the low-amplitude EAC between 13.62 and $13.53 \mathrm{ka}$ and the
Older Dryas in the Bering Sea lamination pattern strongly argues for a close atmospheric coupling between the North Atlantic and the North Pacific without significant time lags. Several previous works have provided evidence for millennial-scale variations in Bering Sea biogenic productivity and upper-ocean characteristics during the last glacial termination that occur in phase with both Greenland and east Asian paleoclimatic reference records (Rella et al., 2012; Itaki et al., 2009; Max et al., 2012; Caissie et al., 2010; Riethdorf et al., 2013b). This in-phase behavior of laminated sediment deposition in warm phases of the deglacial BøllingAllerød (GI-1) interstadial is also known from several locations around the North Pacific Rim (Jaccard and Galbraith, 2012), albeit not on shorter decadal timescales as implied by our study. The oceanographic changes recorded in our sediment core occur with rapidity, comparable to the fast climate changes reported from ice cores (Taylor et al., 1997; Steffensen et al., 2008) or varved lake sediments (Kossler et al., 2011; Brauer et al., 2008).

In the past, studies using general circulation models investigated the teleconnection between the North Atlantic and the North Pacific and possible linkages to changes in the Atlantic Meridional Overturning Circulation (e.g., Mikolajewicz et al., 1997; Vellinga and Wood, 2002; Okumura et al., 2009). In these numerical model experiments cold periods like Heinrich Stadial 1 and the Younger Dryas are simulated by freshwater forcing in the North Atlantic, which leads not only to a weakening of the overturning cell but also to significantly colder temperatures over both the North Atlantic and North Pacific regions. However, while the response over the North Pacific is common in many models, the transfer mechanisms are less well understood, especially on decadal timescales. One important climate determinant for variations in the Bering Sea ocean-atmosphere system is the Aleutian Low as a main action center in the circulation of the Northern Hemisphere (Rodionov et al., 2007). Changes in the strength and location of this system have a direct effect on winter air and sea surface temperatures and thus sea ice occurrence, which in turn influence the strength of the phytoplankton bloom season. Several studies suggest a strong Aleutian Low is associated with warm winters in the Bering Sea (Niebauer, 1983), and that winter temperatures in the Bering Sea are sensitive to the position of the Aleutian Low (Rodionov et al., 2007). It has further been shown that the Aleutian Low varies on decadal timescales and is also associated with variability of the Arctic Oscillation (Overland et al., 1999). We suggest that decadal changes in position and strength of the Aleutian Low lead to colder and warmer winters on decadal timescales. The colder (warmer) winters are connected with increased (decreased) sea ice cover, which is highly sensitive to temperature changes and fosters decreased (increased) diatom blooming events. 


\subsection{Characteristics and causes of millennial- to decadal-scale OMZ development}

The occurrence of laminations serve as a direct indicator for oxygenation decreases below the threshold for most marine benthic life and the development of severe and persistent anoxia in Pacific intermediate water masses. We follow previous works (Behl and Kennett, 1996) in assigning different oxygen concentrations to the different facies in our record. These are as follows: $<0.1 \mathrm{mLL}^{-1} \mathrm{O}_{2}$ excluding any burrowing macrofauna for Laminated Facies; $0.1 \mathrm{mLL}^{-1} \mathrm{O}_{2}$ for Layered Facies, which allows only meiofaunal bioturbation that just diffuses the laminations on millimeter scales but does not lead to deeper bioturbation by larger organisms; $0.1-0.2 \mathrm{mLL}^{-1} \mathrm{O}_{2}$ for Bioturbated Laminae permitting partial homogenization; and $>0.3 \mathrm{mLL}^{-1} \mathrm{O}_{2}$ for the Bioturbated Facies allowing bioturbating macrofauna (Behl and Kennett, 1996).

\subsubsection{Deglacial strengthening and Holocene decline of anoxia in the Bering Sea}

Our facies analysis reveals millennial-scale changes between stadial, well-oxygenated (bioturbated) phases and interstadial, mainly anoxic (laminated/layered) phases during the last glacial termination, consistent with recent assessments (Jaccard and Galbraith, 2012). In our records, Bioturbated Facies occur on millenial scales during the cold stadial Younger Dryas (GS-1) phase and the relatively cold IACP (GI-1b), indicating improved oxygen concentrations in the bottom water at our site. These periods are contrasted with the two interstadial dysoxic-anoxic sediment facies during the entire Bølling (GI-1e)-Allerød (GI-1c) and Preboreal (Fig. 8).

Notably, superimposed on these interstadial warm phases we recorded multiple, rapid facies changes on inter-decadal timescales between Layered and Laminated Facies (Fig. 9). These changes exhibit a shorter-term, subtler process that modulates the mid-depth deglacial Bering Sea oxygen concentration. Though Layered Facies do not show a clear expression of alternating seasonal laminae like in laminated sections, they are devoid of major bioturbation, thus evidencing persistent anoxic to dysoxic conditions. These patterns lead us to distinguish between millennial-scale larger oxygenation changes (between oxic and dysoxic-anoxic) and superimposed decadal-scale smaller fluctuations (between dysoxic and anoxic) as distinct patterns in OMZ strength.

The Laminated and Layered Facies disappear after the Preboreal in the Holocene, indicating both a vertically contracting and abating $\mathrm{OMZ}$ in the Bering Sea compared to deglacial conditions (Fig. 8). As the increasing NGRIP $\delta^{18} \mathrm{O}$ data would suggest ongoing deposition of laminations, changes in the environmental background conditions must have been distinct. Multiple causes are likely. Firstly, alkenone-based SST data show a temperature decrease of more than $3{ }^{\circ} \mathrm{C}$ in the Bering Sea throughout the early Holocene, which might lead to reduced phytoplankton productivity due to shorter and colder summers (Caissie et al., 2010; Riethdorf et al., 2013a). However, SSTs are still higher compared to the Bølling-Allerød, pointing to additional factors besides SSTs that might influence the Holocene OMZ development. Secondly, another potential cause could be a change in the characteristics of mid-depth water masses at our sites in the Bering Sea, either in age (and thus nutrient inventories) or in oxygenation compared to the midlate Holocene. Published ventilation ages reveal no clear Holocene changes in the North Pacific (Duplessy et al., 1989; Ahagon et al., 2003), and the occurrence of oxygen-poor, Layered Facies together with rather unchanged B-P ventilation ages suggests that oxygen depletion of mid-depth waters is not caused by the presence of upwelled older, oxygen-poor North Pacific deep-water masses (cf. 4.5.2). In support of this notion, evidence from Gulf of Alaska sites that lie in the upstream part of waters entering the Bering Sea show oxygenation increases from anoxic-suboxic towards suboxicoxic conditions around 10.9-9.2 ka (Addison et al., 2012; Davies et al., 2011), broadly in line with ceasing anoxia at our site SO202-18-3/6.

An additional factor for the establishment of higher oxygenation potentially is the opening of the Bering Strait at around $11 \mathrm{ka}$ (Elias et al., 1996; Hu et al., 2010). Today, the northward annual through-flow of relatively warm, nutrientrich North Pacific water into the Arctic Ocean is around 0.8 sverdrup (Woodgate et al., 2010). Roughly, during the time of the Bering Strait opening at $11 \mathrm{ka}$ the occurrence of Layered Facies increases until laminations finally disappear at $10 \mathrm{ka}$. As Layered Facies represent slightly higher oxygen concentrations compared to laminated sequences, this change might represent a trend towards decreasing productivity, beginning with the opening of the Bering Strait. Likely, the effect of this gateway opening was not instantaneous but rather steadily increasing and amplified with ongoing sea level rise. Today the gateway influences the lowerproductivity ecosystems of the Chukchi and Beaufort seas with the advection of high nutrient Pacific waters (Grebmeier et al., 2006). As it has further been suggested that higher primary production in the Chukchi Sea also during the Holocene could result from the greater nutrient supply from the Bering Sea (e.g., Keigwin et al., 2006), we suggest the following mechanism: before $11 \mathrm{ka}$ Bering Sea surface ocean circulation was substantially different from modern patterns, with an absent or weakened Anadyr Current and differing expression of the Bering Slope Current, also leading to different interactions with the Alaskan Stream and the open North Pacific. These changes potentially caused a more intense gyre circulation within the Bering Sea, enhanced trapping and recirculation of nutrients and thus higher productivity. We further suggest that the opening of this shallow gateway also led to a decline in the surface stratification as warm, nutrientrich surface waters were transported to the Arctic Sea. Such 


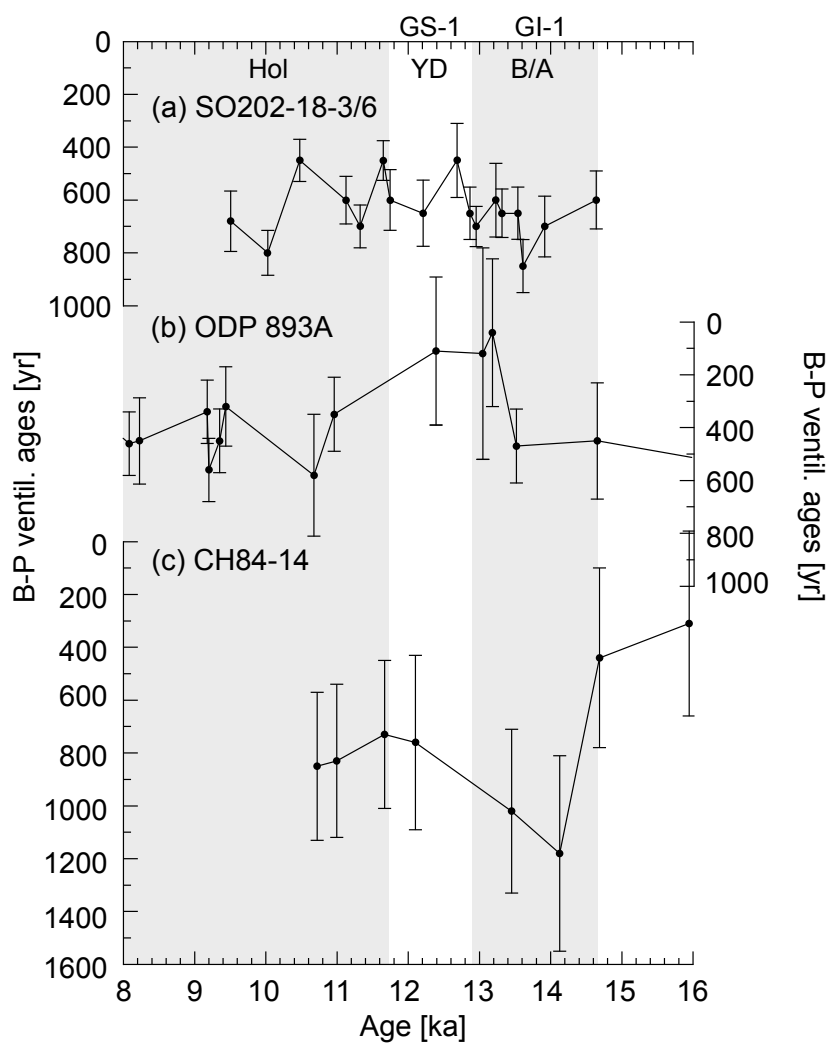

Figure 11. Compilation of ${ }^{14} \mathrm{C}$ paleo-ventilation ages (a) for core SO202-18-3/6, derived from benthic-planktic foraminifera age differences compared to results from (b) the Santa Barbara Basin (Ingram and Kennett, 1995; Roark et al., 2003) and (c) off Japan (Duplessy et al., 1989). Error bars show radiocarbon dating errors. For this comparison, planktic ${ }^{14} \mathrm{C}$ ages of Japan and the Santa Barbara Basin were recalculated using the new INTCAL13 calibration curve and reservoir ages of Sarnthein et al. (2007) for the Santa Barbara Basin. Hol: Holocene; YD: Younger Dryas; B/A: Bølling-Allerød

a trend for declining stratification after the Preboreal in the Bering Sea can be tentatively assumed based on differences between alkenone and $\mathrm{Mg} / \mathrm{Ca}$-based SST starting at about $9 \mathrm{ka}$ (Riethdorf et al., 2013a). As a second factor, the coastline retreated significantly further away from the core position during the flooding of the shallow northern shelf areas in connection with ongoing sea level rise. Thus, the influence of the fluvial input, delivering nutrients and enhancing surface stratification, diminished.

\subsubsection{Millennial-scale changes in intermediate water ventilation}

To identify the potential impact of North Pacific intermediate water circulation and ventilation changes on longer-term, millennial-scale oxygen variations on our sites, we calculated benthic-planktic ventilation ages (Fig. 11). In principle, older B-P ages could indicate the transport of highernutrient, lower-oxygen water masses, such as North Pacific
Deep Water (NPDW) to the Bering Sea and their entrainment into the upper, mid-depth waters, thereby supporting OMZ strengthening. However, our B-P ages show only moderate oscillations throughout the deglacial sequence, with values between 470 and $700{ }^{14} \mathrm{C}$ yr, all significantly below values reported for Pacific Deep Water of $1530 \pm 230{ }^{14} \mathrm{C}$ yr (Lund et al., 2011). Additionally, B-P age oscillations at our sites do not reflect stadial-interstadial changes in ventilation and are with variations of 100-200 yr substantially smaller in amplitude than those reported from distant, more southern middepth locations, e.g., off Japan and the Santa Barbara Basin for the same time interval (Fig. 11; cf. Duplessy et al., 1989; Ahagon et al., 2003; Roark et al., 2003; Kennett and Ingram, 1995). Note that for this comparison planktic ${ }^{14} \mathrm{C}$ ages of Japan and the Santa Barbara Basin were recalculated using the new INTCAL13 calibration curve and reservoir ages of Sarnthein et al. (2007) for the Santa Barbara Basin. One potential reason for the small oscillations could be that the Bering Sea is remote from the formation area of the most prominent mid-depth water mass, North Pacific Intermediate Water (NPIW), which has a strong influence on the ventilation off Japan. Our B-P ventilation age data do not support a collapse of subarctic North Pacific mid-depth water circulation during GI-1 and the Preboreal. As a result, we do not consider that physical forcing leading to NPIW formation rate or source region changes play a decisive role in the development and vertical expansion of interstadial anoxia at mid-depth in the Bering Sea.

However, for the Gulf of California and the Santa Barbara Basin it was suggested that phases of oxic and dysoxic conditions were controlled by changes in oxygen concentration of upper intermediate water (Kennett and Ingram, 1995; Hendy et al., 2002). Based on analyses of laminated sediments from the North American continental margin, Zheng et al. (2000) suggested suppressed ventilation at higher latitudes of the North Pacific during the Bølling-Allerød. In line with these assumptions, epibenthic $\delta^{13} \mathrm{C}$ data from the Alaska Margin (Davies et al., 2011) and from the modern formation regions of NPIW (Max et al., 2014) show major decreases in middepth oxygenation during the Bølling-Allerød. We thus assume that changes in NPIW oxygen concentrations are an important factor for conditioning the mid-depth waters in the Bering Sea on millennial timescales. Oxygen decreases can be caused by high export production and subsequent higher mid-depth remineralization of exported organic matter along the pathway of NPIW in the Pacific subarctic gyre without significant changes in the formation rate of NPIW (Crusius et al., 2004). This scenario would be in line with our radiocarbon B-P age ventilation data and is supported by a number of studies indicating widespread export productivity peaks during the Bølling-Allerød and the Preboreal throughout the North Pacific (Brunelle et al., 2010; Kohfeld and Chase, 2011), combined with reductions in oxygen concentrations along the pathway of NPIW throughout the North Pacific (Hendy and Pedersen, 2006; McKay et al., 2005). 


\subsubsection{Modulation of OMZ strength during the Bølling-Allerød (GI-1) and Preboreal}

Increased export production through higher biogenic productivity leads to an intensification of the OMZ through organic matter degradation. Generally, higher primary productivity is indicated by various productivity proxies. Increased $\mathrm{Ca} / \mathrm{Ti}$ ratios (Fig. 4) and carbonate mass accumulation rates (Fig. S3) might be caused by higher carbonate production through coccolithophorids (Okazaki et al., 2005; Khim et al., 2010). Further, the low Ti concentrations during the laminated intervals, higher biogenic opal mass accumulation rate (Fig. S3), and high $\mathrm{Si} / \mathrm{Ti}$ ratios in the biogenic laminae (Fig. 7) point to increased seasonal export production. Regionally increased bio-siliceous productivity during the Preboreal and Bølling-Allerød was also shown for the southern Bering Sea (Gorbarenko et al., 2005) and in nearby, partly laminated, core PC23A (Fig. 1; Khim et al., 2010; Katsuki et al., 2014). Several environmental factors can influence the biological productivity and OMZ development.

1. Higher bottom water temperatures at our site during the warmer Bølling-Allerød phases would increase the remineralization of organic matter at the seafloor, as metabolic rates of organisms increase with higher temperatures (Matsumoto et al., 2007). Such a process could work independently of surface ocean processes as a positive feedback, contributing to elevated oxygen consumption in intermediate waters. Unfortunately, regional bottom water temperature reconstructions from North Pacific sites are to our knowledge not available to provide information on the importance of such a process. However, a qualitative assessment of potential temperature changes based on published benthic oxygen isotope records from comparable water depths shows no unambiguous trends. On Shirshov Ridge, values show a glacial-interglacial amplitude change of $1.95 \%$ (Riethdorf et al., 2013), and in the eastern Bering Sea of ca. 1.4\%o (Rella et al., 2012).

2. During peak glaciation, the biological productivity was restricted by a shorter and colder summer that led to the spatial extension of sea ice (Takahashi, 2005; Nakatsuka et al., 1995). Higher temperatures during the BøllingAllerød and since the onset of the Holocene (Max et al., 2012; Riethdorf et al., 2013a) would have supported an earlier retreat of sea ice and a change from longer and more pronounced, sometimes multi-year sea ice cover during cold phases like Heinrich Stadial 1 and Younger Dryas to shorter, seasonal sea ice seasons. This is in line with evidence based on diatom assemblages from the Umnak Plateau (Caissie et al., 2010), which indicates during the Bølling-Allerød a shift from perennial to seasonal sea ice and a pattern similar to the ice-related bloom in the marginal ice zone on the Bering Shelf today.
3. Regionally elevated rates of primary productivity ultimately require high-nutrient surface water concentrations. On the NE Bering Sea margin, these can be delivered through several sources. High meltwater input by fluvial runoff from retreating North American hinterland glaciers would provide additional nutrients through lateral transport of terrigenous material, most likely delivered during warmer episodes (Sancetta et al., 1984; Itaki et al., 2009). In addition, nutrient increase was likely enhanced to a significant extent by the deglacial sea level rise, leading to the flooding of the previously exposed, wide, shallow proximal northern Bering Sea shelf. This process would have provided additional nutrients compared to the modern situation, as suggested for similar settings with laminated sediments from the southeast Alaska Margin (Davies et al., 2011). Another process influencing the amount of biological productivity is light, depending on upper ocean stratification, which can constitute the limiting factor in biogenic productivity especially in high latitudes (Kohfeld et al., 2005). Before the Bølling-Allerød, enhanced upper-ocean mixing potentially increased light limitation by a deeper mixed layer. With the onset of the Bølling, input of meltwater from the North American ice sheets stratified the upper water column and fostered biological productivity (Lam et al., 2013; Katsuki et al., 2014) as it would enable phytoplankton to prolong their growth season and better use the more abundant bio-available nutrients in the upper photic zone (Niebauer et al., 1995; Niebauer and Alexander, 1985). Such changes in freshwater-induced stratification might also work fast enough to explain the observed decadalscale correspondence of fine laminations to higher temperatures (Fig. 10).

In summary, we presume that major forcing of OMZ was likely a combination of sea ice changes, with less sea ice during the warm phases and variations in ocean stratification with a more stratified upper water due to freshwater input.

However, the anoxic-dysoxic bottom waters during the Older Dryas (GI-1d) and the EAC did not ameliorate to a point that would permit strong bioturbation, but just enabled the observed meiofauna-induced dispersal of annual layer structures on millimeter scales. Had instead the former been the case, the layered structure of the sediment would have been destroyed by larger-scale macrofauna bioturbation. A further increase in oxygenation, despite the lower productivity in these cold phases, was likely prevented by the still comparably low oxygen concentrations of mid-depth water entering the Bering Sea.

Taken together, we see two major processes that contribute to the strengthening of the $\mathrm{OMZ}$ in the Bering Sea and thus the formation of laminated sediments. Based on rather constant ventilation ages, we observe millennial-scale changes in the NPIW oxygen concentrations 
withoutsignificant variations in the formation rate of NPIW. This millennial-scale pattern, however, apparently did not drive oxygen concentrations below the critical threshold for anoxic conditions and lamina formation (i.e., $<0.1 \mathrm{~mL} \mathrm{~L}^{-1}$ ). Oxygen concentrations decreased to that extent only in combination with higher regional export production and subsequent remineralization of organic matter during the warm phases of the Bølling-Allerød. Our results corroborate earlier hypotheses that argued for oxygen drawdown in the North Pacific by a combination of higher organic matter export and lower $\mathrm{O}_{2}$ concentrations at intermediate waters (Zheng et al., 2000; Crusius et al., 2004). Other possible forcing mechanisms connected to indices like the Pacific Decadal Oscillation or to solar forcing are currently under discussion (e.g., Katsuki et al., 2014) and at present cannot be corroborated based on the data presented in this story.

\section{Summary and conclusions}

Two laminated cores from the northern Bering Slope located in intermediate water depths allow for a tight coupling to Greenland ice core data on decadal timescales, especially for the deglacial Bølling-Allerød phase (GI-1, 14.64-12.85 ka). By correlating a suite of laminated sediment intervals to NGRIP oxygen isotope data, we established an age model partly independent from radiocarbon dating, which in turn was used to calculate marine reservoir ages. Mean reservoir ages are $875 \mathrm{yr}$ for the Bølling-Allerød (GI-1), $910 \mathrm{yr}$ for the Younger Dryas (GS-1), and $770 \mathrm{yr}$ for the Preboreal. The correlation and laminae counts implied the presence of annually layered sediment sections (varves). The combined information from sediment facies analysis and microscale high-resolution XRF scanning showed that the laminations represent an annual alternation of high bio-siliceous spring/summer blooming events driven by the sea ice retreat and a rather siliciclastic background sedimentation.

Our results show for the first time that the mid-depth water column in the Bering Sea reacted quickly on inter-decadal timescales to changes in upper-ocean characteristics, particularly in regard to sea ice dynamics, surface water stratification, and sea surface temperatures. Potential implications for the future arise from these observations of rapid changes. It is unclear whether oxygen concentrations could drop again to anoxic levels if temperature increases and sea ice decreases continue along present trends (e.g., Brown and Arrigo, 2012; Grebmeier, 2006), leading to the expansion of subarctic Pacific "death zones". This would create significant consequences and large-scale ecosystem readjustments.

On millennial, or stadial to interstadial, timescales relatively constant benthic-planktic ventilation ages reveal that the OMZ development is more likely caused by basin-wide mid-depth remineralization of organic matter in intermediate waters, rather than changes in formation rate or sources of intermediate water masses. On decadal timescales, the for- mation of laminated sediments during the Bølling-Allerød seems to be effectively coupled to warm temperatures, as expressed in NGRIP ice core $\delta^{18} \mathrm{O}$ and Bering Sea SST data. This tight correlation with warm phases during the BøllingAllerød in the ice core data implies a close atmospheric teleconnection to North Atlantic and Greenland climate. During these warm intervals, rapid sea ice and temperature-induced decadal-interannual-scale export productivity changes lead to fine modulations of OMZ strength between anoxic and dysoxic conditions. Comparison with other laminated cores from the Bering Sea shows that during the last deglaciation the OMZ expanded to greater water depths, possibly of more than $3000 \mathrm{~m}$ at some locations. The disappearance of the laminations during the Holocene might be coupled to the opening of the Bering Strait.

\section{The Supplement related to this article is available online at doi:10.5194/cp-10-2215-2014-supplement.}

Acknowledgements. We thank the captain, crew, and scientific party of R/V Sonne for their support during cruise SO-202 (INOPEX). Lars Max and Jian Ren provided comments and suggestions that improved this paper. We thank Susanne Wiebe, Ute Bock, and Rita Fröhlking (AWI) for technical support, and Sascha Plewe and Rainer Bahlo (IOW) for support with the ITRAX core scanner. We acknowledge financial support by the Alfred-Wegener-Institute, Helmholtz Centre for Polar and Marine Research; the MARUM - Center for Marine Environmental Sciences (Project OC 3); and funding by the German Federal Ministry of Education and Research (BMBF Grant no. 03G0202A) for the INOPEX (Innovative NOrth Pacific EXperiment) project.

Edited by: T. Kiefer

\section{References}

Addison, J. A., Finney, B. P., Dean, W. E., Davies, M. H., Mix, A. C., Stoner, J. S., and Jaeger, J. M.: Productivity and sedimentary $\delta^{15} \mathrm{~N}$ variability for the last 17000 years along the northern Gulf of Alaska continental slope, Paleoceanography, 27, PA1206, doi:10.1029/2011PA002161, 2012.

Ahagon, N., Ohkushi, K., Uchida, M., and Mishima, T.: Mid-depth circulation in the northwest Pacific during the last deglaciation: Evidence from foraminiferal radiocarbon ages, Geophys. Res. Lett., 30, 2097, doi:10.1029/2003GL018287, 2003.

Andersen, K. K., Svensson, A., Johnsen, S. J., Rasmussen, S. O., Bigler, M., Röthlisberger, R., Ruth, U., Siggaard-Andersen, M.-L., Steffensen, J. P., Dahl-Jensen, D., Vinther, B. M., and Clausen, H. B.: The Greenland Ice Core Chronology 2005, 15$42 \mathrm{ka}$ - Part 1: constructing the time scale, Quaternary Sci. Rev., 25, 3246-3257, 2006.

Bauch, D., Erlenkeuser, H., Winckler, G., Pavlova, G., and Thiede, $\mathrm{J}$.: Carbon isotopes and habitat of polar planktic foraminifera in 
the Okhotsk Sea: the "carbonate ion effect" under natural conditions, Mar. Micropaleontol., 45, 83-99, 2002.

Behl, R. J. and Kennett, J. P.: Brief interstadial events in the Santa Barbara basin, NE Pacific, during the past $60 \mathrm{kyr}$, Nature, 379, 243-246, 1996.

Blockley, S. P. E., Lane, C. S., Hardiman, M., Rasmussen, S. O., Seierstad, I. K., Steffensen, J. P., Svensson, A., Lotter, A. F., Turney, C. S., and Bronk Ramsey, C.: Synchronisation of palaeoenvironmental records over the last 60000 years, and an extended INTIMATE event stratigraphy to 48000 b2k, Quaternary Sci. Rev., 36, 2-10, 2011.

Brauer, A., Haug, G. H., Dulski, P., Sigman, D. M., and Negendank, J. F. W.: An abrupt wind shift in western Europe at the onset of the Younger Dryas cold period, Nat. Geosci., 1, 520-523, 2008.

Bronk Ramsey, C., Staff, R. A., Bryant, C. L., Brock, F., Kitagawa, H., van der Plicht, J., Schlolaut, G., Marshall, M. H., Brauer, A., Lamb, H. F., Payne, R. L., Tarasov, P. E., Haraguchi, T., Gotanda, K., Yonenobu, H., Yokoyama, Y., Tada, R., and Nakagawa, T.: A complete terrestrial radiocarbon record for 11.2 to $52.8 \mathrm{kyr}$ B.P, Science (New York, NY), 338, 370-374, 2012.

Brown, Z. W. and Arrigo, K. R.: Contrasting trends in sea ice and primary production in the Bering Sea and Arctic Ocean, ICES J. Mar. Sci., 69, 1180-1193, 2012.

Brunelle, B. G., Sigman, D. M., Jaccard, S. L., Keigwin, L. D., Plessen, B., Schettler, G., Cook, M. S., and Haug, G. H.: Glacial/interglacial changes in nutrient supply and stratification in the western subarctic North Pacific since the penultimate glacial maximum, Quaternary Sci. Rev., 29, 2579-2590, 2010.

Bubenshchikova, N., Nuernberg, D., Lembke-Jene, L., and Pavlova, G.: Living benthic foraminifera of the Okhotsk Sea: Faunal composition, standing stocks and microhabitats, Mar. Micropaleontol., 69, 314-333, 2008.

Caissie, B. E., Brigham-Grette, J., Lawrence, K. T., Herbert, T. D., and Cook, M. S.: Last Glacial Maximum to Holocene sea surface conditions at Umnak Plateau, Bering Sea, as inferred from diatom, alkenone, and stable isotope records, Paleoceanography, 25, PA1206, doi:10.1029/2008PA001671, 2010.

Cook, M. S., Keigwin, L. D., and Sancetta, C. A.: The deglacial history of surface and intermediate water of the Bering Sea, DeepSea Res. Pt. II, 52, 2163-2173, 2005.

Croudace, I. W., Rindby, A., and Rothwell, R. G.: ITRAX: description and evaluation of a new multi-function X-ray core scanner, in: New Techniques in Sediment Core Analysis, edited by: Rothwell, R. G., Special Publications, The Geological Society, London, 51-63, 2006.

Crusius, J., Pedersen, T., Kienast, S., Keigwin, L., and Labeyrie, L.: Influence of northwest Pacific productivity on North Pacific Intermediate Water oxygen concentrations during the BoilingAllerod interval (14.7-12.9 ka), Geology, 32, 633-636, 2004.

Danielson, S., Curchitser, E., Hedstrom, K., Weingartner, T., and Stabeno, P.: On ocean and sea ice modes of variability in the Bering Sea, J. Geophys. Res., 116, C12034, doi:10.1029/2011JC007389, 2011.

Davies, M. H., Mix, A. C., Stoner, J. S., Addison, J. A., Jaeger, J., Finney, B., and Wiest, J.: The deglacial transition on the southeastern Alaska Margin: Meltwater input, sea level rise, marine productivity, and sedimentary anoxia, Paleoceanography, 26, PA2223, doi:10.1029/2010PA002051, 2011.
Duplessy, J.-C., Arnold, M., Bard, E., Juillet-Leclerc, A., Kallel, N., and Labeyrie, L.: AMS C-14 Study of Transient Events and of the Ventilation Rate of the Pacific Intermediate Water During the Last Deglaciation, Radiocarbon, 31, 493-502, 1989.

Elias, S. A., Short, S. K., Nelson, C. H., and Birks, H. H.: Life and times of the Bering land bridge, Nature, 382, 60-63, 1996.

Galbraith, E. D., Jaccard, S. L., Pedersen, T. F., Sigman, D. M., Haug, G. H., Cook, M., Southon, J. R., and Francois, R.: Carbon dioxide release from the North Pacific abyss during the last deglaciation, Nature, 449, 890-893, 2007.

Garcia, H. E., Locarnini, R. A., Boyer, T. P., Antonov, J. I., Baranova, O. K., Zweng, M. M., and Johnson, D. R.: World Ocean Atlas 2009, Volume 3: Dissolved Oxygen, Apparent Oxygen Utilization, and Oxygen Saturation, NOAA Atlas NESDIS 70, edited by: Levitus, S., US Government Printing Office, Washington, DC, 344 pp., 2010.

Gebhardt, H., Sarnthein, M., Grootes, P. M., Kiefer, T., Kühn, H., Schmieder, F., and Röhl, U.: Paleonutrient and productivity records from the subarctic North Pacific for Pleistocene glacial terminations I to V, Paleoceanography, 23, PA4212, doi:10.1029/2007PA001513, 2008.

Gersonde, R.: The Expedition of the Research Vessel "Sonne" to the Subpolar North Pacific and the Bering Sea in 2009 (SO202INOPEX), in: Reports on Polar and Marine Research, Alfred Wegener Institute, Bremerhaven, 323 pp., 2012.

Gorbarenko, S. A., Basov, I. A., Chekhovskaya, M. P., Southon, J., Khusid, T. A., and Artemova, A. V.: Orbital and millennium scale environmental changes in the southern Bering Sea during the last glacial-Holocene: Geochemical and paleontological evidence, Deep-Sea Res. Pt. II, 52, 2174-2185, 2005.

Grebmeier, J. M.: A Major Ecosystem Shift in the Northern Bering Sea, Science (New York, NY), 311, 1461-1464, 2006.

Grebmeier, J. M., Cooper, L. W., Feder, H. M., and Sirenko, B. I.: Ecosystem dynamics of the Pacific-influenced Northern Bering and Chukchi Seas in the Amerasian Arctic, Progress in Oceanography, 71, 331-361, 2006.

Hendy, I. L., Kennett, J. P., Roark, E. B., and Ingram, B. L.: Apparent synchroneity of submillennial scale climate events between Greenland and Santa Barbara Basin, California from 30-10 ka, Quaternary Sci. Rev., 21, 1167-1184, 2002.

Hendy, I. L. and Pedersen, T. F.: Oxygen minimum zone expansion in the eastern tropical North Pacific during deglaciation, Geophys. Res. Lett., 33, L20602, doi:10.1029/ 2006GL025975, 2006.

Hu, A. X., Meehl, G. A., Otto-Bliesner, B. L., Waelbroeck, C., Han, W. Q., Loutre, M. F., Lambeck, K., Mitrovica, J. X., and Rosenbloom, N.: Influence of Bering Strait flow and North Atlantic circulation on glacial sea-level changes, Nat. Geosci., 3, 118-121, 2010.

Hughen, K. A., Southon, J. R., Lehman, S. J., and Overpeck, J. T.: Synchronous radiocarbon and climate shifts during the last deglaciation, Science (New York, NY), 290, 1951-1954, 2000.

Ikehara, K., Ohkushi, K. a. i., Shibahara, A., and Hoshiba, M.: Change of bottom water conditions at intermediate depths of the Oyashio region, NW Pacific over the past 20000 yrs, Glob. Planet. Change, 53, 78-91, 2006.

Itaki, T., Uchida, M., Kim, S., Shin, H.-S., Tada, R., and Khim, B.K.: Late Pleistocene stratigraphy and palaeoceanographic implications in northern Bering Sea slope sediments: evidence from 
the radiolarian species Cycladophora davisiana, J. Quaternary Sci., 24, 856-865, 2009.

Jaccard, S. L. and Galbraith, E. D.: Large climate-driven changes of oceanic oxygen concentrations during the last deglaciation, Nat. Geosci., 5, 151-156, 2012.

Katsuki, K., Itaki, T., Khim, B-K., Uchida, M., and Tada, R.:Response of the Bering Sea to 11-year solar irradiance cycles during the Bølling-Allerød, Geophys. Res. Lett., 41, 2892-2898, 2014.

Keigwin, L., Jones, G., and FROELICH, P.: A 15,000 Year Paleoenvironmental Record from Meiji Seamount, far Northwestern Pacific, Earth Planet. Sci. Lett., 111, 425-440, 1992.

Keigwin, L. D.: Glacial-age hydrography of the far northwest Pacific Ocean, Paleoceanography, 13, 323-339, 1998.

Keigwin, L. D., Donnelly, J. P., Cook, M. S., Driscoll, N. W., and Brigham-Grette, J.: Rapid sea-level rise and Holocene climate in the Chukchi Sea, Geology, 34, 861-864, 2006.

Kennett, J. and Ingram, B.: A 20000 Year Record of Ocean Circulation and Climate Change from the Santa Barbara Basin, Nature, 377, 510-514, 1995.

Khim, B.-K., Kim, S., Uchida, M., and Itaki, T.: High organic carbon deposition in the northern margin of the Aleutian Basin (Bering Sea) before the last deglaciation, Oc. Sci. J., 45, 203211, 2010.

Kim, S., Khim, B. K., Uchida, M., Itaki, T., and Tada, R.: Millennial-scale paleoceanographic events and implication for the intermediate-water ventilation in the northern slope area of the Bering Sea duriing the last 71 kyrs, Glob. Planet. Change, 79, 89-98, 2011.

Kohfeld, K. E. and Chase, Z.: Controls on deglacial changes in biogenic fluxes in the North Pacific Ocean, Quaternary Sci. Rev., 30, 3350-3363, 2011.

Kossler, A., Tarasov, P., Schlolaut, G., Nakagawa, T., Marshall, M., Brauer, A., Staff, R., Ramsey, C. B., Bryant, C., Lamb, H., Demske, D., Gotanda, K., Haraguchi, T., Yokoyama, Y., Yonenobu, H., and Tada, R.: Onset and termination of the lateglacial climate reversal in the high-resolution diatom and sedimentary records from the annually laminated SG06 core from Lake Suigetsu, Japan, Palaeogeogr. Palaeocl., 306, 103-115, doi:10.1016/j.palaeo.2011.04.004, 2011.

Kuhn, G.: Don't forget the salty soup: Calculations for bulk marine geochemistry and radionuclide geochronology, Mineral. Mag., 77, 1516, doi:10.1180/minmag.2013.077.5.11, 2013.

Kuroyanagi, A., Kawahata, H., Nishi, H., and Honda, M. C.: Seasonal changes in planktonic foraminifera in the northwestern North Pacific Ocean: sediment trap experiments from subarctic and subtropical gyres, Deep-Sea Res. Pt. II, 49, 5627-5645, 2002.

Lam, P. J., Robinson, L. F., Blusztajn, J., Li, C., Cook, M. S., McManus, J. F., and Keigwin, L. D.: Transient stratification as the cause of the North Pacific productivity spike during deglaciation, Nat. Geosci., 6, 622-626, 2013.

Levitus, S. and Boyer, T. P.: World Ocean Atlas 1994, Volume 4: Temperature, in: NOAA Atlas NESDIS 4, US Government Printing Office, Washington, DC, 117 pp., 1994.

Luchin, V. A., Menovshchikov, V. A., Lavrentiev, V. M., and Reed, R. K.: Thermohaline Structure and Water Masses in the Bering Sea, in: Dynamics of the Bering Sea, edited by: Loughlin, T. R., and Ohtani, K., North Pacific MArine Science Organization
(PICES) and Alaska Sea Grant College Program, Fairbanks, AL, 29-60, 1999.

Lund, D. C., Mix, A. C., and Southon, J.: Increased ventilation age of the deep northeast Pacific Ocean during the last deglaciation, Nat. Geosci., 4, 771-774, 2011.

Mangerud, J., Andersen, S. T., Berglund, B. E., and Donner, J. J.: Quaternary stratigraphy of Norden, a proposal for terminology and classification, Boreas, 3, 109-126, 1974.

Matsumoto, K., Hashioka, T., and Yamanaka, Y.: Effect of temperature-dependent organic carbon decay on atmospheric $p \mathrm{CO}_{2}$, J. Geophys. Res., 112, G02007, doi:10.1029/2006JG000187, 2007.

Max, L., Riethdorf, J.-R., Tiedemann, R., Smirnova, M., LembkeJene, L., Fahl, K., Nürnberg, D., Matul, A., and Mollenhauer, G.: Sea surface temperature variability and sea-ice extent in the subarctic northwest Pacific during the past 15000 years, Paleoceanography, 27, PA3213, doi:10.1029/2012PA002292, 2012.

Max, L., Lembke-Jene, L., Riethdorf, J. R., Tiedemann, R., Nürnberg, D., Kühn, H., and Mackensen, A.: Pulses of enhanced North Pacific Intermediate Water ventilation from the Okhotsk Sea and Bering Sea during the last deglaciation, Clim. Past, 10, 591-605, doi:10.5194/cp-10-591-2014, 2014.

McKay, J. L., Pedersen, T. F., and Southon, J.: Intensification of the oxygen minimum zone in the northeast Pacific off Vancouver Island during the last deglaciation: Ventilation and/or export production?, Paleoceanography, 20, PA4002, doi:10.1029/2003PA000979, 2005.

Mikolajewicz, U., Crowley, T. J., Schiller, A., and Voss, R.: Modelling teleconnections between the North Atlantic and North Pacific during the Younger Dryas, Nature, 387, 384-387, 1997.

Mix, A., Lund, D., Pisias, N., Boden, P., Bornmalm, L., Lyle, M., and Pike, J.: Rapid climate oscillations in the northeast Pacific during the last deglaciation reflect Northern and Southern Hemisphere sources, in: Mechanisms of Global Climate Change at Millennial Time Scales, edited by: Clark, P. U., Webb, R. S., and Keigwin, L. D., Geophysical Monograph Series, American Geophysical Union, Washington, DC, 127-148, 1999.

Müller, P. J. and Schneider, R.: An automated leaching method for the determination of opal in sediments and particulate matter, Deep-Sea Res. Pt. I, 40, 425-444, 1993.

Nakagawa, T., Gotanda, K., Haraguchi, T., Danhara, T., Yonenobu, H., Brauer, A., Yokoyama, Y., Tada, R., Takemura, K., Staff, R. A., Payne, R., Bronk Ramsey, C., Bryant, C., Brock, F., Schlolaut, G., Marshall, M., Tarasov, P., and Lamb, H.: SG06, a fully continuous and varved sediment core from Lake Suigetsu, Japan: stratigraphy and potential for improving the radiocarbon calibration model and understanding of late Quaternary climate changes, Quaternary Sci. Rev., 36, 164-176, 2012.

Nakatsuka, T., Watanabe, K., Handa, N., Matsumoto, E., and Wada, E.: Glacial to Interglacial Surface Nutrient Variations of Bering Deep Basins Recorded by $\mathrm{d}^{13} \mathrm{C}$ and $\mathrm{d}^{15} \mathrm{~N}$ of Sedimentary Organic-Matter, Paleoceanography, 10, 1047-1061, 1995.

Nederbragt, A. J. and Thurow, J. W.: A $6000 \mathrm{yr}$ varve record of Holocene climate in Saanich Inlet, British Columbia, from digital sediment colour analysis of ODP Leg 169S cores, Mar. Geol., 174, 95-110, 2001.

Nederbragt, A. J. and Thurow, J. W.: Amplitude of ENSO cycles in the Santa Barbara Basin, off California, during the past 15000 years, J. Quaternary Sci., 20, 447-456, 2005. 
NGRIP-Members, Andersen, K. K., Azuma, N., Barnola, J. M., Bigler, M., Biscaye, P., Caillon, N., Chappellaz, J., Clausen, H. B., DahlJensen, D., Fischer, H., Flückiger, J., Fritzsche, D., Fujii, Y., Goto-Azuma, K., Gronvold, K., Gundestrup, N. S., Hansson, M., Huber, C., Hvidberg, C. S., Johnsen, S. J., Jonsell, U., Jouzel, J., Kipfstuhl, S., Landais, A., Leuenberger, M., Lorrain, R., Masson-Delmotte, V., Miller, H., Motoyama, H., Narita, H., Popp, T., Rasmussen, S. O., Raynaud, D., Röthlisberger, R., Ruth, U., Samyn, D., Schwander, J., Shoji, H., SiggardAndersen, M. L., Steffensen, J. P., Stocker, T., Sveinbjornsdottir, A. E., Svensson, A., Takata, M., Tison, J. L., Thorsteinsson, T., Watanabe, O., Wilhelms, F., and White, J. W. C.: High-resolution record of Northern Hemisphere climate extending into the last interglacial period, Nature, 431, 147-151, 2004.

Niebauer, H. J.: Sea ice and temperature variability in the eastern Bering Sea and the relation to atmospheric fluctuations, J. Geophys. Res.-Oceans, 85, 7507-7515, 1980.

Niebauer, H. J.: Multiyear sea ice variability in the eastern Bering Sea: An update, J. Geophys. Res.-Oceans, 88, 2733-2742, 1983.

Niebauer, H. J. and Alexander, V.: Oceanographic frontal structure and biological production at an ice edge, Cont. Shelf Res., 4, 367-388, 1985 .

Niebauer, H. J., Alexander, V., and Henrichs, S. M.: A time-series study of the spring bloom at the Bering Sea ice edge I. Physical processes, chlorophyll and nutrient chemistry, Cont. Shelf Res., 15, 1859-1877, 1995.

Nuernberg, D. and Tiedemann, R.: Environmental change in the Sea of Okhotsk during the last 1.1 million years, Paleoceanography, 19, PA4011, doi:10.1029/2004PA001023, 2004.

Okada, M., Takagi, M., Narita, H., and Takahashi, K.: Chronostratigraphy of sediment cores from the Bering Sea and the subarctic Pacific based on paleomagnetic and oxygen isotopic analysis, Deep-Sea Res. Pt. II, 52, 2092-2109, 2005.

Okazaki, Y., Takahashi, K., Asahi, H., Katsuki, K., Hori, J., Yasuda, H., Sagawa, Y., and Tokuyama, H.: Productivity changes in the Bering Sea during the late Quaternary, Deep-Sea Res. Pt. II, 52, 2150-2162, 2005.

Okumura, Y. M., Deser, C., Hu, A., Timmermann, A., and Xie, S.P.: North Pacific Climate Response to Freshwater Forcing in the Subarctic North Atlantic: Oceanic and Atmospheric Pathways, J. Climate, 22, 1424-1445, 2009.

Ortiz, J. D., O’Connell, S. B., Delviscio, J., Dean, W., Carriquiry, J. D., Marchitto, T., Zheng, Y., and Van Geen, A.: Enhanced marine productivity off western North America during warm climate intervals of the past $52 \mathrm{kyr}$, Geology, 32, 521-524, 2004.

Overland, J. E., Adams, J. M., and Bond, N. A.: Decadal variability of the Aleutian low and its relation to high-latitude circulation, J. Climate, 12, 1542-1548, 1999.

Paulmier, A. and Ruiz-Pino, D.: Oxygen minimum zones (OMZs) in the modern ocean, Prog. Oceanogr., 80, 113-128, 2009.

Praetorius, S. K. and Mix, A. C.: Synchronization of North Pacific and Greenland climates preceeded abrupt deglacial warming, Science, 345, 444-448, 2014.

Rasmussen, S., Andersen, K., Svensson, A., Steffensen, J., Vinther, B., Clausen, H., Siggaard-Andersen, M., Johnsen, S., Larsen, L., Dahl-Jensen, D., Bigler, M., Rothlisberger, R., Fischer, H., Goto-Azuma, K., Hansson, M., and Ruth, U.: A new Greenland ice core chronology for the last glacial termination, J. Geophys.
Res.-Atmospheres, 111, D06102, doi:10.1029/2005JD006079, 2006.

Rasmussen, S. O., Vinther, B. M., Clausen, H. B., and Andersen, K. K.: Early Holocene climate oscillations recorded in three Greenland ice cores, Quaternary Sci. Rev., 26, 1907-1914, 2007.

Reimer, P. J., Bard, E., Bayliss, A., Beck, J. W., Blackwell, P. G., Bronk Ramsey, C., Buck, C. E., Cheng, H., Edwards, R. L., Friedrich, M., Grootes, P. M., Thomas, P. G., Haflidason, H., Hajdas, I., Hatte, C., Heaton, T. J., Hoffmann, D. L., Hogg, A. G., Hughen, K. A., Kaiser, K. F., Kromer, B., Manning, S. W., Niu, M., Reimer, R. W., Richards, D. A., Scott, E. M., Southon, J. R., Staff, R. A., Turney, C. S. M., and van der Plicht, J.: INTCAL13 and MARINE13 Radiocarbon Age Calibration Curves 0-50 000 years cal. BP, Radiocarbon, 55, 1869-1887, 2013.

Rella, S. F., Tada, R., Nagashima, K., Ikehara, M., Itaki, T., Ohkushi, K. i., Sakamoto, T., Harada, N., and Uchida, M.: Abrupt changes of intermediate water properties on the northeastern slope of the Bering Sea during the last glacial and deglacial period, Paleoceanography, 27, PA3203, doi:10.1029/2011PA002205, 2012.

Ren, J., Gersonde, R., Esper, O., and Sancetta, C.: Diatom distributions in northern North Pacific surface sediments and their relationship to modern environmental variables, Palaeogeography, Palaeoclimatology, Palaeoecology, 402, 81-103, doi:10.1016/j.palaeo.2014.03.008, 2014.

Reynolds, R. W., Rayner, N. A., Smith, T. M., Stokes, D. C., and Wang, W.: An improved in situ and satellite SST analysis for climate, J. Climate, 15, 1609-1625, 2002.

Riethdorf, J.-R., Max, L., Nürnberg, D., Lembke-Jene, L., and Tiedemann, R.: Deglacial history of (sub) sea surface temperatures and salinity in the subarctic NW Pacific: Implications for upper-ocean stratification, Paleoceanography, 28, 91-104, 2013a.

Riethdorf, J. R., Nürnberg, D., Max, L., Tiedemann, R., Gorbarenko, S. A., and Malakhov, M. I.: Millennial-scale variability of marine productivity and terrigenous matter supply in the western Bering Sea over the past 180 kyr, Clim. Past, 9, 1345-1373, doi:10.5194/cp-9-1345-2013, 2013b.

Roark, E. B., Ingram, B. L., Southon, J., and Kennett, J. P.: Holocene foraminiferal radiocarbon record of paleocirculation in the Santa Barbara Basin, Geology, 31, 379-382, 2003.

Rodionov, S. N., Bond, N. A., and Overland, J. E.: The Aleutian Low, storm tracks, and winter climate variability in the Bering Sea, Deep-Sea Res. Pt. II, 54, 2560-2577, 2007.

Ruth, U., Bigler, M., Röthlisberger, R., Siggaard-Andersen, M.-L., Kipfstuhl, S., Goto-Azuma, K., Hansson, M. E., Johnsen, S. J., Lu, H., and Steffensen, J. P.: Ice core evidence for a very tight link between North Atlantic and east Asian glacial climate, Geophys. Res. Lett., 34, L03706, doi:10.1029/2006GL027876, 2007.

Sancetta, C., Heusser, L., Labeyrie, L., Naidu, A. S., and Robinson, S. W.: Wisconsin Holocene Paleoenvironment of the Bering Sea - Evidence from Diatoms, Pollen, Oxygen Isotopes and ClayMinerals, Mar. Geol., 62, 55-68, 1984.

Sarnthein, M., Grootes, P. M., Kennett, J. P., and Nadeau, M.: ${ }^{14} \mathrm{C}$ Reservoir Ages Show Deglacial Changes in Ocean Currents and Carbon Cycle, in: Ocean Circulation: Mechanisms and Impacts, 1st ed., edited by: Schmittner, A., Chiang, J., and Hemming, S., Geophys. Monogr. Ser., 173, American Geophysical Union, Washington, 175-196, 2007. 
Sarnthein, M., Schneider, B., and Grootes, P. M.: Peak glacial ${ }^{14} \mathrm{C}$ ventilation ages suggest major draw-down of carbon into the abyssal ocean, Clim. Past, 9, 2595-2614, doi:10.5194/cp-92595-2013, 2013.

Schlitzer, R.: Interactive analysis and visualization of geoscience data with Ocean Data View, Comput. Geosci., 28, 1211-1218, 2002.

Schlung, S. A., Christina Ravelo, A., Aiello, I. W., Andreasen, D. H., Cook, M. S., Drake, M., Dyez, K. A., Guilderson, T. P., Lariviere, J. P., Stroynowski, Z., and Takahashi, K.: Millennial-scale climate change and intermediate water circulation in the Bering Sea from $90 \mathrm{ka}$ : A high-resolution record from IODP Site U1340, Paleoceanography, 28, 54-67, doi:10.1029/2012PA002365, 2013.

Shibahara, A., Ohkushi, K., Kennett, J. P., and Ikehara, K.: Late Quaternary changes in intermediate water oxygenation and oxygen minimum zone, northern Japan: A benthic foraminiferal perspective, Paleoceanography, 22, PA3213, doi:10.1029/2005PA001234, 2007.

Southon, J. and Fedje, D.: A post-glacial record of $14 \mathrm{C}$ reservoir ages for the British Columbia coast, Can. J. Archaeol., 27, 95$111,2003$.

Springer, A. M., McRoy, C. P., and Flint, M. V.: The Bering Sea Green Belt: shelf-edge processes and ecosystem production, Fish. Oceanogr., 5, 205-223, 1996.

Staff, R. A., Nakagawa, T., Schlolaut, G., Marshall, M. H., Brauer, A., Lamb, H. F., Bronk Ramsey, C., Bryant, C. L., Brock, F., Kitagawa, H., van der Plicht, J., Payne, R. L., Smith, V. C., Mark, D. F., MacLeod, A., Blockley, S. P. E., Schwenninger, J.-L., Tarasov, P. E., Haraguchi, T., Gotanda K., Yonenobu, H., Yokoyama, Y., and Suigetsu 2006 Project Members.: The multiple chronological techniques applied to the Lake Suigetsu SG06 sediment core, Japan, Boreas, 42, 259-266, 2012.

Steffensen, J. P., Andersen, K. K., Bigler, M., Clausen, H. B., DahlJensen, D., Fischer, H., Goto-Azuma, K., Hansson, M., Johnsen, S. J., Jouzel, J., Masson-Delmotte, V., Popp, T., Rasmussen, S. O., Rothlisberger, R., Ruth, U., Stauffer, B., Siggaard-Andersen, M. L., Sveinbjornsdottir, A. E., Svensson, A., and White, J. W. C.: High-Resolution Greenland Ice Core Data Show Abrupt Climate Change Happens in Few Years, Science (New York, NY), 321, 680-684, 2008.

Stuiver, M. and Polach, H.: Discussion: Reporting of ${ }^{14} \mathrm{C}$ Data, Radiocarbon, 19, 355-363, 1977.

Stuiver, M. and Reimer, P. J.: Extended ${ }^{14} \mathrm{C}$ database and revised CALIB radiocarbon calibration program, Radiocarbon, 35, 215230, 1993.

Takahashi, K.: The Bering Sea and paleoceanography, Deep-Sea Res. Pt. II, 52, 2080-2091, 2005.
Takahashi, K., Fujitani, N., and Yanada, M.: Long term monitoring of particle fluxes in the Bering Sea and the central subarctic Pacific Ocean, 1990-2000, Prog. Oceanogr., 55, 95-112, 2002.

Takahashi, K., Ravelo, A. C., Alvarez Zarikian, C., and Expedition323Scientists: Bering Sea Paleoceanography Expedition 323 of the riserless drilling platform. Victoria, British Columbia (Canada), to Yokohama, Japan; Sites U1339-U1345; 5 July4 September 2009, in: Proceedings of the Integrated Ocean Drilling Program, Volume 323, Integrated Ocean Drilling Program Management International, Inc., Tokyo, 2011.

Tanaka, S. and Takahashi, K.: Late Quaternary paleoceanographic changes in the Bering Sea and the western subarctic Pacific based on radiolarian assemblages, Deep-Sea Res. Pt. II, 52, 2131-2149, 2005.

Taylor, K. C., Mayewski, P. A., Alley, R. B., Brook, E. J., Gow, A. J., Grootes, P. M., Meese, D. A., Saltzman, E. S., Severinghaus, J. P., Twickler, M. S., White, J. W. C., Whitlow, S., and Zielinski, G. A.: The Holocene-Younger Dryas Transition Recorded at Summit, Greenland, Science (New York, NY), 278, 825-827, 1997.

Telford, R. J., Heegaard, E., and Birks, H. J. B.: The intercept is a poor estimate of a calibrated radiocarbon age, The Holocene, 14, 296-298, 2004.

Tjallingii, R., Rohl, U., Kolling, M., and Bickert, T.: Influence of the water content on X-ray fluorescence core-scanning measurements in soft marine sediments, Geochem. Geophy. Geosy., 8, Q02004, doi:10.1029/2006GC001393, 2007.

Tsunogai, S., Kusakabe, M., Iizumi, H., Koike, I., and Hattori, A.: Hydrographic features of the deep water of the Bering Sea - The Sea of Silica, Deep-Sea Res. Pt. A, 26, 641-659, 1979.

van der Plicht, J., van Geel, B., Bohncke, S. J. P., Bos, J. A. A., Blaauw, M., Speranza, A. O. M., Muscheler, R., and Bjorck, S.: The Preboreal climate reversal and a subsequent solar-forced climate shift, J. Quaternary Sci., 19, 263-269, 2004.

Vellinga, M. and Wood, R. A.: Global climatic impacts of a collapse of the Atlantic thermohaline circulation, Clim. Change, 54, 251267, 2002.

Watanabe, S., Tada, R., Ikehara, K., Fujine, K., and Kido, Y.: Sediment fabrics, oxygenation history, and circulation modes of Japan Sea during the Late Quaternary, Palaeogeogr. Palaeocl., 247, 50-64, 2007.

Woodgate, R. A., Weingartner, T., and Lindsay, R.: The 2007 Bering Strait oceanic heat flux and anomalous Arctic sea-ice retreat, Geophys. Res. Lett., 37, L01602, doi:10.1029/2009GL041621, 2010.

Zheng, Y., Van Geen, A., Anderson, R. F., Gardner, J. V., and Dean, W. E.: Intensification of the northeast Pacific oxygen minimum zone during the Bolling-Allerod warm period, Paleoceanography, 15, 528-536, 2000. 